\title{
Synthesis and Characterization of New Schiff Bases Derived from N (1)-Substituted Isatin with Dithiooxamide and Their Co(II), Ni(II), Cu(II), Pd(II), and Pt(IV) Complexes
}

\author{
Ahlam J. Abdul-Ghani and Asmaa M. N. Khaleel \\ Department of Chemistry, College of Science, University of Baghdad, Jaderiya, P.O. Box 47059 Baghdad, Iraq \\ Correspondence should be addressed to Asmaa M. N. Khaleel, asmaa_mnk@yahoo.com \\ Received 13 April 2009; Revised 12 July 2009; Accepted 15 July 2009 \\ Recommended by Nick Katsaros
}

Three new Schiff bases of $\mathrm{N}$-substituted isatin $\mathrm{L}_{\mathrm{I}}, \mathrm{L}_{\mathrm{II}}$, and $\mathrm{L}_{\mathrm{III}}=$ Schiff base of $\mathrm{N}$-acetylisatin, N-benzylisatin, and N-benzoylisatin, respectively, and their metal complexes $\mathrm{C}_{1 \mathrm{a}, \mathrm{b}}=\left[\mathrm{Co}_{2}\left(\mathrm{~L}_{\mathrm{I}}\right)_{2} \mathrm{Cl}_{3}\right] \mathrm{Cl}, \mathrm{C}_{2}=\left[\mathrm{Ni}\left(\mathrm{L}_{\mathrm{I}}\right)_{2} \mathrm{Cl}_{2}\right] 0.4 \mathrm{BuOH}, \mathrm{C}_{3}=\left[\mathrm{CuL}_{\mathrm{I}} \mathrm{Cl}\left(\mathrm{H}_{2} \mathrm{O}\right)\right] \mathrm{Cl} \cdot 0.5 \mathrm{BuOH}$, $\mathrm{C}_{4}=\left[\mathrm{Pd}\left(\mathrm{L}_{\mathrm{I}}\right)_{2} \mathrm{Cl}\right] \mathrm{Cl}, \mathrm{C}_{5}=\left[\mathrm{Pt}\left(\mathrm{L}_{1}\right)_{2} \mathrm{Cl}_{2}\right] \mathrm{Cl}_{2} \cdot 1.8 \mathrm{EtOH} . \mathrm{H}_{2} \mathrm{O}, \mathrm{C}_{6 \mathrm{a}}=\left[\mathrm{CoL}_{\mathrm{II}} \mathrm{Cl}\right] \mathrm{Cl} \cdot 0.4 \mathrm{H}_{2} \mathrm{O} \cdot 0.3 \mathrm{DMSO}, \mathrm{C}_{6 \mathrm{~b}}=[\mathrm{CoL} / \mathrm{Cl}] \mathrm{Cl} \cdot 0.3 \mathrm{H}_{2} \mathrm{O} \cdot$ $0.1 \mathrm{BuOH}, \mathrm{C}_{7}=\left[\mathrm{NiL}_{\mathrm{II}} \mathrm{Cl}_{2}\right], \mathrm{C}_{8}=\left[\mathrm{CuL}_{\mathrm{II}}\right] \mathrm{Cl}_{2} \cdot \mathrm{H}_{2} \mathrm{O}, \mathrm{C}_{9}=\left[\mathrm{Pd}\left(\mathrm{L}_{\mathrm{II}}\right)_{2}\right] \mathrm{Cl}_{2}, \mathrm{C}_{10}=\left[\mathrm{Pt}\left(\mathrm{L}_{\mathrm{II}}\right)_{2.5} \mathrm{Cl}_{1} \mathrm{Cl}_{3}, \mathrm{C}_{11 \mathrm{a}}=\left[\mathrm{Co}\left(\mathrm{L}_{\mathrm{III}}\right)\right] \mathrm{C}_{12} \cdot \mathrm{H}_{2} \mathrm{O}\right.$, $\mathrm{C}_{11 \mathrm{~b}}=\left[\mathrm{Co}\left(\mathrm{L}_{\mathrm{III}}\right)\right] \mathrm{Cl}_{2} \cdot 0.2 \mathrm{H}_{2} \mathrm{O}$, and $\mathrm{C}_{12}=\left[\mathrm{Ni}\left(\mathrm{L}_{\mathrm{III}}\right)_{2}\right] \mathrm{Cl}_{2}, \mathrm{C}_{13}=\left[\mathrm{Ni}\left(\mathrm{L}_{\mathrm{III}}\right)_{2}\right] \mathrm{Cl}_{2}$ were reported. The complexes were characterized by elemental analyses, metal and chloride content, spectroscopic methods, magnetic moments, conductivity measurements, and thermal studies. Some of these compounds were tested as antibacterial and antifungal agents against Staphylococcus aureus, Proteus vulgaris, Candida albicans, and Aspergillus niger.

Copyright (c) 2009 A. J. Abdul-Ghani and A. M. N. Khaleel. This is an open access article distributed under the Creative Commons Attribution License, which permits unrestricted use, distribution, and reproduction in any medium, provided the original work is properly cited.

\section{Introduction}

Isatin (indole-2,3-dione) and its derivatives have shown a wide scale of biological activities such as antibacterial [1-3], antifungal $[1,3-5]$, anticonvulsant $[2,6]$, anti-HIV [7], anticancer [1,2], antiviral [1], and enzyme inhibitors [2]. The Schiff bases (a) and (b) (Scheme 1) derived from isatin and its derivatives with different amines have been studied [1, 2, 6, 8-13]. The reaction of N-acetyl, N-benzoyl, and $\mathrm{N}$-tosylisatin and their Schiff base derivatives (c) and (d) (Scheme 1) with ethanol, methanol, isopropyl alcohol, allyl alcohol, $\mathrm{TsNH}_{2}$, pyrrolidine, and water yield products resulting from nucleophilic attack at the C-2 carbonyl that leads to heterocyclic ring cleavage $[8,14]$. The present work aims to study the synthesis and antibacterial activity of three new ligands derived from condensation of $\mathrm{N}$-acetyl, $\mathrm{N}$-benzyl, and N-benzoylisatin with the chelating agent dithiooxamide (ethanedithioamide or rubeanic acid) $d t o$ and their metal complexes. The Schiff bases of dithiooxamide and their complexes have received most of the attention because of the semiconductive, magnetic, spectroscopic, and thermal properties [15-17] as well as being used as semiconductors antibacterial and antifungal agents [18-20].

\section{Experimental/Materials and Methods}

All chemicals used were of analytical reagent grade (AR) except dto and ethanol which were purified prior to use [21]. FTIR spectra were recorded on SHIMADZU FTIR8400S, Fourier Transform, Infrared spectrophotometer. The electronic spectra $(\lambda(200-1100) \mathrm{nm})$ in different solvents were recorded on Shimadzu (UV-Vis)-160 spectrophotometer. Elemental microanalyses were performed on Euro vector EA $3000 \mathrm{~A}$. The metal contents of the complexes were determined by atomic absorption technique using Varian-AA775, Atomic Absorption Spectrophotomer. Mass spectra were recorded on Shimadzu QP 5050A. ${ }^{1} \mathrm{H}$ NMR was performed by using Bruker Ultra Sheild $300 \mathrm{MHz}$ NMR spectrophotometer. Thermal analyses (TG and DTG) were carried out by using Shimadzu Thermal Analyzer Type $50 \mathrm{H}$. Electrical conductivity measurements for complexes 
$\mathrm{R}_{1}=\mathrm{H}, \mathrm{COCH}_{3}, \mathrm{COph}, \mathrm{CH}_{2} \mathrm{ph}$

$\mathrm{R}_{2}=$ Various substituted and non substituted aromatic and heterocyclic rings

(a)<smiles>[R]N=C(C([R])=O)c1ccccc1NC(C)=O</smiles>

$\mathrm{R}=\mathrm{OH}$ $\mathrm{R}^{\prime}=\mathrm{NHOH}$

(c)<smiles>[R2]N=C1C(=O)N([R1])c2ccccc21</smiles>

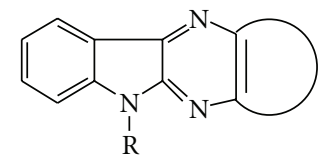

$\mathrm{R}=\mathrm{COCH}_{3}, \mathrm{CH}_{2} \mathrm{ph}, \mathrm{COph}$

(b)

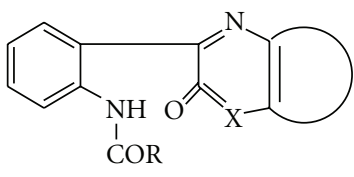

$\mathrm{R}=\mathrm{CH}_{3}, \mathrm{ph}$

$\mathrm{X}=\mathrm{N}, \mathrm{O}, \mathrm{S}$

(d)
Scheme 1: Schiff bases of isatin derivatives.

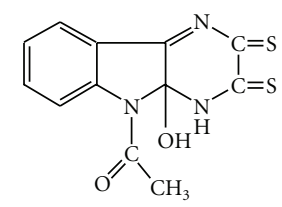

$\mathrm{L}_{\mathrm{I}}$

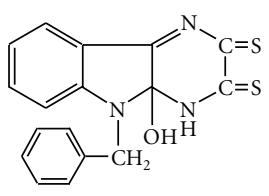

$\mathrm{L}_{\mathrm{II}}$

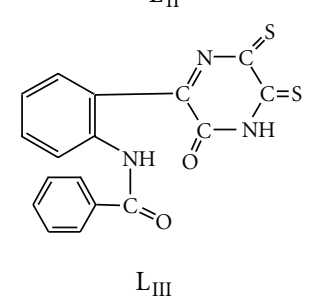

Scheme 2: The structures of the prepared ligands $\mathrm{L}_{\mathrm{I}}, \mathrm{L}_{\mathrm{II}}$, and $\mathrm{L}_{\mathrm{III}}$.

$\left(10^{-3} \mathrm{M}\right)$ in DMF and DMSO at room temperature were carried out by using Hunts Capacitors Trade Mark British made. Magnetic moments ( $\mu_{\text {eff. }}$ B.M) for the prepared complexes in the solid state at room temperature were measured by using Bruker Magnet B.M-6. The chloride content for complexes was determined by Mohr's method. N-acetylisatin, Nbenzylisatin, $\mathrm{N}$-benzoylisatin, and $\mathrm{PdCl}_{2}(\mathrm{phCN})_{2}$ were prepared by methods reported in literature $[6,22-25]$.

\section{Synthesis of Ligands}

All attempts to prepare 1-(9a-Hydroxy-2,3-dithiooxo-1, 2,3,9a-tetrahydro-1,4,9-triaza-fluoren-9-yl)-ethanone $\left(\mathrm{L}_{\mathrm{I}}\right)$ (Scheme 2) and 9-Benzyl-9a-hydroxy-9,9a-dihydro-1H1,4,4-triaza-fluorene-2,3-dithione $\left(\mathrm{L}_{\mathrm{II}}\right)$ (Scheme 2) in solutions were unsuccessful; therefore solid reaction was carried out to prepare the two ligands.

3.1. Schiff Base of N-Acetylisatin: 1-(9a-Hydroxy-2,3-dithiooxo-1,2,3,9a-tetrahydro-1,4,9-triaza-fluoren-9-yl)-ethanone $\left(L_{I}\right)$. A powdered mixture of $\mathrm{N}$-acetylisatin $(0.3092 \mathrm{~g}$, $1.6 \mathrm{mmol})$ and $d$ to $(0.0983 \mathrm{~g}, 0.8 \mathrm{mmol})$ in a sealed Carius tube was heated in a stirred oil bath at $160-170^{\circ} \mathrm{C}$ for 2 hours. The melt colour was changed from orange to dark brown. After cooling to room temperature, the solid product was ground and dissolved in butanol, followed by precipitation with ether. A black precipitate was formed. The product was filtered off and washed several times with ether to remove the unreacted materials giving brown crystals. Yield $(0.116 \mathrm{~g}$, $48.76 \%)$, m.p $\left(220^{\circ} \mathrm{C}\right.$ decomp.). ${ }^{1} \mathrm{H}$ NMR data $\delta(\mathrm{ppm})$, $\left(\mathrm{CDCL}_{3}\right): 2.508\left(3 \mathrm{H}, \mathrm{s}, \mathrm{CH}_{3}\right) ; 3.34(2 \mathrm{H}, \mathrm{s}, \mathrm{OH}$ and $\mathrm{NH}$ thioamide); 7.074-7.853 (4H, $\mathrm{m}$, aromatic protons). MS(EI), $\mathrm{m} / \mathrm{z}(\%):$ 207(21), 161(10), 146(23), 133(9), 92(10), 78(59), 63(84), 44(100). Anal. for $\mathrm{C}_{12} \mathrm{H}_{9} \mathrm{~N}_{3} \mathrm{O}_{2} \mathrm{~S}_{2}$ Calcd. C, 49.48; $\mathrm{H}$, 3.09 ; N, 14.43\%; Found: C, 50.54; H, 3.22; N, 13.23\%.

3.2. Schiff Base of N-Benzylisatin: 9-Benzyl-9a-hydroxy9,9a-dihydro-1H-1,4,4-triaza-fluorene-2,3-dithione $\left(L_{I I}\right)$. A powdered mixture of N-benzylisatin $(0.829 \mathrm{~g}, 3.5 \mathrm{mmol})$ and dto $(0.85 \mathrm{~g}, 7 \mathrm{mmol})$ was heated in a sealed Carius tube in an oil bath at $140^{\circ} \mathrm{C}$ for 10 hours. Colour of melt was changed from orange to dark brown. After cooling to room temperature, a solid mass was formed. The product was ground and purified several times in refluxing ethanol, filtered off, washed with hot ethanol followed by acetone and dried, giving dark brown crystals. Yield $(0.2679 \mathrm{~g}, 22.3 \%)$, m.p $\left(>250^{\circ} \mathrm{C}\right) .{ }^{1} \mathrm{H}$ NMR data $\delta(\mathrm{ppm}),(\mathrm{DMSO}): 3.45(2 \mathrm{H}$, s, $\mathrm{OH}$ and $\mathrm{NH}$ thioamide); $5.1\left(2 \mathrm{H}\right.$, w, $\mathrm{CH}_{2}$ benzyl $)$; 6.97.2(9H, m, aromatic protons). MS(EI), m/z(\%): 156(11), 149(15), 127(13), 105(11), 78(100), 63(100). Anal. for $\mathrm{C}_{17} \mathrm{H}_{13} \mathrm{~N}_{3} \mathrm{OS}_{2}$ Calcd.: C, 60.17; H, 3.83; N, 12.38\%; Found: C, $61.10 ; \mathrm{H}, 3.43 ; \mathrm{N}, 12.98 \%$.

3.3. Schiff Base of N-Benzoylisatin: N-[2-(3-oxo-5,6-dithioxo3,4,5,6-tetrahydro-pyrazin-2-yl)-phenyl] benzamide ( $\left.L_{I I I}\right)$. Equimolar amounts of benzoylisatin $(0.2 \mathrm{~g}, 0.79 \mathrm{mmol})$ and dto $(0.0957 \mathrm{~g}, 0.79 \mathrm{mmol})$ in butanol $\left(2 \mathrm{~cm}^{3}\right)$ containing 4 drops of piperidine were heated under reflux with stirring for 5 hours during which the colour of solution was changed from orange to brown. The solution mixture was left to stand overnight and then cooled down to $0^{\circ} \mathrm{C}$. Cold ether was added until a dark brown precipitate was formed. The product was filtered off, washed several times with acetone followed by ether. Yield $(0.0857 \mathrm{~g}, 30.51 \%)$, m.p. (250 ${ }^{\circ} \mathrm{C}$ decomp.), ${ }^{1} \mathrm{H}$ NMR data (ppm), (DMSO): 4.9025.101(1H, b, NH thioamide); 7.144-7.860(9H, m, aromatic protons); 10.124(1H, b, NH benzoyl moiety). MS(EI), 
m/z(\%): 296.6(13), 267.5(7), 232.6(20), 195.6(15), 149.5(6), 104.4(27), 83.4(6). Anal. for $\mathrm{C}_{17} \mathrm{H}_{11} \mathrm{~N}_{3} \mathrm{O}_{2} \mathrm{~S}_{2}$ Calcd.: C, 57.79; H, 3.11; N, 11.89\%; Found: C, 57.39; H, 3.54; N, 11.30\%.

\section{Preparation of Metal Complexes}

(A) A solution mixture of the ligands $\mathrm{L}_{\mathrm{I}}$ and $\mathrm{L}_{\mathrm{II}}$ $(0.01 \mathrm{mmol})(0.0029,0.0033 \mathrm{~g})$, respectively, with the metal salts $\mathrm{CoCl}_{2} \cdot 6 \mathrm{H}_{2} \mathrm{O}, \mathrm{NiCl}_{2} \cdot 6 \mathrm{H}_{2} \mathrm{O}$, and $\mathrm{CuCl}_{2} \cdot 2 \mathrm{H}_{2} \mathrm{O}(0.01 \mathrm{mmol})$ and $(0.02 \mathrm{mmol})(0.0058$, $0.0067 \mathrm{~g}$ ) of $\mathrm{L}_{\mathrm{I}}$ and $\mathrm{L}_{\mathrm{II}}$, respectively, with the metal salts $\mathrm{PdCl}_{2}(\mathrm{phCN})_{2}$ and $\mathrm{K}_{2} \mathrm{PtCl}_{6}(0.01 \mathrm{mmol})$, in $\operatorname{DMF}\left(\mathrm{C}_{1}\right)$, butanol $\left(\mathrm{C}_{2}\right.$ and $\left.\mathrm{C}_{3}\right)$, or DMSO $\left(\mathrm{C}_{4}-\mathrm{C}_{10}\right)$ was heated under reflux for four hours. Precipitation of $\mathrm{L}_{\mathrm{I}}$ complexes took place within 30 minutes, while those of $\mathrm{L}_{\text {II }}$ was precipitated at the end of reflux time. The products were filtered, washed with hot ethanol and acetone, followed by ether and vacuum dried. Complexes of $\mathrm{L}_{\mathrm{III}}$ were prepared in the same manner using a mixture of $\mathrm{L}_{\mathrm{III}}(0.01 \mathrm{mmol}$, $0.0035 \mathrm{~g}$ ) with the metal salts $\mathrm{CoCl}_{2} \cdot 6 \mathrm{H}_{2} \mathrm{O}$, $\mathrm{NiCl}_{2} \cdot 6 \mathrm{H}_{2} \mathrm{O} \quad(0.01 \mathrm{mmol})$ and $(0.02 \mathrm{mmol}$, $0.007 \mathrm{~g})$ of $\mathrm{L}_{\mathrm{III}}$ with $\mathrm{PdCl}_{2}(\mathrm{phCN})_{2}(0.01 \mathrm{mmol})$. "C $\mathrm{C}_{\mathrm{a}}$ ": colour(dark brown) Yield (26.24\%). Anal. for $\left(\mathrm{C}_{24} \mathrm{H}_{18} \mathrm{~N}_{6} \mathrm{O}_{4} \mathrm{~S}_{4} \mathrm{Co}_{2} \mathrm{Cl}_{3}\right) \mathrm{Cl}$ Calcd.: C, 34.21; $\mathrm{H}, 2.13$; N, 9.97; S, 15.20\%; Found: C, 34.32; $\mathrm{H}, 2.50 ; \mathrm{N}, 9.42 ; \mathrm{S}, 15.13 \%$. M, 13.99(Calcd), 14.0(Found)\%; Cl, 16.86(Calcd), 16.20(Found)\%. " $\mathrm{C}_{2}$ ": colour(dark brown). Yield $(23.51 \%)$. Anal. for $\left[\left(\mathrm{C}_{24} \mathrm{H}_{18} \mathrm{~N}_{6} \mathrm{O}_{4} \mathrm{~S}_{4} \mathrm{NiCl}_{2}\right) 0.4\left(\mathrm{C}_{4} \mathrm{H}_{10} \mathrm{O}\right)\right]$ Calcd.: C, 47.63; H, 5.75; N, 8.33\%; Found: C, 48.32; H, 5.45; N, 8.83\%. M, 5.82(Calcd), 5.72(Found)\%. "C $\mathrm{C}_{3}$ ": colour(dark brown). Yield (23.35\%). Anal. for $\left[\left(\mathrm{C}_{12} \mathrm{H}_{9} \mathrm{~N}_{3} \mathrm{O}_{2} \mathrm{~S}_{2} \mathrm{CuCl} \quad\left(\mathrm{H}_{2} \mathrm{O}\right)\right) \mathrm{Cl} .0 .5\left(\mathrm{C}_{4} \mathrm{H}_{10} \mathrm{O}\right)\right]$ Calcd.: C, 34.96; H, 3.32; N, 8.74\%; Found: C, 34.01; H, 3.72; N, 9.73\%. M, 13.21(Calcd), 13.85(Found)\%. Cl, 14.77(Calcd), 14.70(Found\%). "C 4 ": colour(dark brown). Yield (35.18\%). Anal. for $\left[\left(\mathrm{C}_{24} \mathrm{H}_{18} \mathrm{~N}_{6} \mathrm{O}_{4} \mathrm{~S}_{4} \mathrm{PdCl}\right) \mathrm{Cl}\right]$ Calcd.: C, 37.94; $\mathrm{H}, 2.37$; N, 11.06; S, 16.86\%; Found: C, 38.40; $\mathrm{H}, 2.38 ; \mathrm{N}, 11.15 ; \mathrm{S}, 16.78 \%$. M, 13.96(Calcd), 13.71(Found)\%. Cl, 9.35(Calcd), 10.5(Found)\%. "C $\mathrm{C}_{5}$ ": colour(brown). yield (19.08\%). Anal. for $\left[\left(\mathrm{C}_{24} \mathrm{H}_{18} \mathrm{~N}_{6} \mathrm{O}_{4} \mathrm{~S}_{4} \mathrm{PtCl}_{2}\right) \mathrm{Cl}_{2} \cdot 1.8\left(\mathrm{C}_{2} \mathrm{H}_{6} \mathrm{O}\right) \cdot \mathrm{H}_{2} \mathrm{O}\right]$ Calcd.: C, 32.47; H, 3.02; N, 8.23\%; Found: C, 32.85; H, 3.27; N, 9.16\%. M, 19.12(Calcd), 19.10(Found)\%. "C 6 ": colour(dark brown). Yield (36.06\%). Anal. for $\left[\left(\mathrm{C}_{17} \mathrm{H}_{13} \mathrm{~N}_{3} \mathrm{OS}_{2} \mathrm{CoCl}\right) \mathrm{Cl} \cdot 0.4\left(\mathrm{H}_{2} \mathrm{O}\right) \cdot 0.3\left(\mathrm{C}_{2} \mathrm{H}_{6} \mathrm{SO}\right)\right]$ Calcd.: C, 42.28; H, 3.12; N, 8.40; S, 12.81\%; Found: C, 41.85; H, 2.72; N, 8.15; S, $12.00 \%$. M, 11.79(Calcd), 12.11(Found)\%; Cl, 14.21(Calcd), 14.58(Found)\%. " $\mathrm{C}_{7}$ ": colour(dark brown). Yield (45.30\%). Anal. for $\left[\mathrm{C}_{17} \mathrm{H}_{13} \mathrm{~N}_{3} \mathrm{OS}_{2} \mathrm{NiCl}_{2}\right]$ Calcd.: C, 43.52; H, 2.77; N, 8.96\%; Found: C, 44.20; H, 3.05; N, 9.24\%. M, 12.52(Calcd), 12.23(Found)\%; Cl, 15.14(Calcd), 15.47(Found)\%. "C ". colour(dark brown). Yield (45.39\%). Anal. for $\left.\left[\left(\mathrm{C}_{17} \mathrm{H}_{13} \mathrm{~N}_{3} \mathrm{OS}_{2} \mathrm{Cu}\right) \mathrm{Cl}_{2} \cdot \mathrm{H}_{2} \mathrm{O}\right)\right]$ Calcd.: C, 41.50;
H, 3.05; N, 8.54\%; S, 13.02\%; Found: C, 42.15; $\mathrm{H}, 2.74 ; \mathrm{N}, 8.16 ; \mathrm{S}, 12.94 \%$. M, 12.91(Calcd), 13.12(Found)\%; Cl, 14.44(Calcd), 14.55(Found)\%. "C9": colour(dark brown). Yield (43.38\%). Anal. for $\left.\left[\left(\mathrm{C}_{34} \mathrm{H}_{26} \mathrm{~N}_{6} \mathrm{O}_{2} \mathrm{~S}_{4} \mathrm{Pd}\right) \mathrm{Cl}_{2}\right)\right]$ Calcd.: C, 47.71; $\mathrm{H}, 3.04$; N, 9.82\%; S, 14.97\%; Found: C, 47.75; $\mathrm{H}, 3.11$; N, 9.69; S, 15.52\%. M, 12.39(Calcd), 13.00(Found)\%; Cl, 8.30(Calcd), 8.47(Found)\%. " $\mathrm{C}_{10}$ ": colour(dark brown). Yield (32.42\%). Anal. for [( $\left.\left.\left(\mathrm{C}_{17} \mathrm{H}_{13} \mathrm{~N}_{3} \mathrm{OS}_{2}\right)_{2.5} \mathrm{PtCl}\right) \mathrm{Cl}_{3}\right]$ Calcd.: C, 43.05; H, 2.74; N, 8.86\%; S, 13.50\%; Found: C, 43.84; H, 2.55; N, 9.17; S, 14.09\%. M, 16.46(Calcd), 15.87(Found)\%. " $\mathrm{C}_{11 \mathrm{a}}$ ": colour(brown). Yield (33.43\%). Anal. for [ $\left.\left(\mathrm{C}_{17} \mathrm{H}_{11} \mathrm{~N}_{3} \mathrm{O}_{2} \mathrm{~S}_{2} \mathrm{Co}\right) \mathrm{Cl}_{2} \cdot \mathrm{H}_{2} \mathrm{O}\right]$ Calcd.: C, 40.72; $\mathrm{H}$, 2.59; N, 8.38 \%; Found: C, 40.05; H, 2.34; N, 7.82;\%. M, 11.75(Calcd), 12.25(Found)\%. Cl, 14.17(Calcd), 14.85(Found)\%. " $\mathrm{C}_{12}$ ": colour(brown). Yield (34.37\%). Anal. for $\left[\left(\mathrm{C}_{34} \mathrm{H}_{22} \mathrm{~N}_{6} \mathrm{O}_{4} \mathrm{~S}_{4} \mathrm{Ni}\right) \mathrm{Cl}_{2}\right]$ Calcd.: C, 48.82; H, 2.63; N, 10.05\%; Found: C, 49.62; H, 2.46; N, 9.41; \%. M, 7.02(Calcd), 7.50(Found)\%. Cl, 8.49(Calcd), 8.56(Found)\%. " $\mathrm{C}_{13}$ ": colour(brown). Yield (34.03\%). Anal. for $\left[\left(\mathrm{C}_{34} \mathrm{H}_{22} \mathrm{~N}_{6} \mathrm{O}_{4} \mathrm{~S}_{4} \mathrm{Pd}\right) \mathrm{Cl}_{2}\right]$ Calcd.: C, 46.20; H, 2.46; N, 9.51; S, 14.49\%; Found: C, 46.47; H, 2.66; N, 9.79; S, 14.78\%. M, 12.00(Calcd), 11.50(Found)\%. Cl, 8.04(Calcd), 8.63(Found)\%.

(B) To a solution mixture of $\mathrm{N}$-acetyl, N-benzyl, or N-benzoylisatin (0.02 mmol) 0.0037, 0.0047, and $0.005 \mathrm{~g}$, respectively, with dto $(0.01 \mathrm{mmol})$ $(0.0012 \mathrm{~g}), \quad(0.04 \mathrm{mmol}) \quad(0.0048 \mathrm{~g})$, and $(0.02$ $\mathrm{mmol})(0.0024 \mathrm{~g})$, respectively, in butanol was added a solution of $\mathrm{CoCl}_{2} \cdot 6 \mathrm{H}_{2} \mathrm{O}(0.02 \mathrm{mmol})$ in butanol. The mixture was heated under reflux. Precipitation took place immediately. Heating was continued for 4 hours to achieve complet precipitation. The product was filtered, washed with hot butanol, followed by ethanol, acetone, ether, and vacuum dried. "C $1 \mathrm{~b}$ ": colour(dark brown). Yield (25.15\%). Anal. for $\left(\mathrm{C}_{24} \mathrm{H}_{18} \mathrm{~N}_{6} \mathrm{O}_{4} \mathrm{~S}_{4} \mathrm{Co}_{2} \mathrm{Cl}_{3}\right) \mathrm{Cl}$ Calcd.: C, 34.21; H, 2.13; N, 9.97; S, 15.20\%; Found: C, 34.15; H, 1.95; N, 10.31; S, 15.07\%. M, 13.99(Calcd), 13.30(Found)\%; Cl, 16.86(Calcd), 16.19(Found)\%. "C $6 \mathrm{~b}$ ": colour(dark brown). Yield (71.42\%). Anal. for $\left[\left(\mathrm{C}_{17} \mathrm{H}_{13} \mathrm{~N}_{3} \mathrm{OS}_{2} \mathrm{CoCl}\right)\right.$ $\left.\mathrm{Cl} \cdot 0.3\left(\mathrm{H}_{2} \mathrm{O}\right) \cdot 0.1\left(\mathrm{C}_{4} \mathrm{H}_{10} \mathrm{O}\right)\right] \quad$ Calcd.: C, 43.34; $\mathrm{H}, 3.03$; N, 8.71; S, 13.28\%; Found: C, 43.89; $\mathrm{H}, 3.35 ; \mathrm{N}, 8.54 ; \mathrm{S}, 13.48 \%$. M, 12.22(Calcd), 12.25(Found)\%; Cl, 14.73(Calcd), 14.44(Found)\%. " $\mathrm{C}_{11 \mathrm{~b}}$ ": colour(brown). Yield (41.72\%). Anal. for [ $\left.\left(\mathrm{C}_{17} \mathrm{H}_{11} \mathrm{~N}_{3} \mathrm{O}_{2} \mathrm{~S}_{2} \mathrm{Co}\right) \mathrm{Cl}_{2} \cdot 0.2 \mathrm{H}_{2} \mathrm{O}\right]$ Calcd.: C, 41.93; $\mathrm{H}, 2.34$; N, 8.63\%; Found: C, 42.56; H, 2.53; N, 8.73; \%. M, 12.10(Calcd), 12.11(Found)\%. Cl, 14.59(Calcd), 14.71(Found)\%.

\section{Microbiological Test Methods}

The two following methods were used to perform the antimicrobial tests. 
5.1. Agar Diffusion Method. In this method the colonies of the selected bacteria, namely, Staphylococcus aureus $\left(\mathrm{G}^{+}\right)$, Proteus vulgaris $\left(\mathrm{G}^{-}\right)$, and the fungus Candida albicans were spread on the surface of solidified nutrient agar. Suitably separated $7 \mathrm{~mm}$ diameter holes were made in each agar plate. Each hole was injected with $0.1 \mathrm{~mL}$ of $150,350,650$, and $1000 \mathrm{ppm}$ of the studied compound in DMSO. The agar plates were incubated at $37^{\circ} \mathrm{C}$ for 24 hours. Diameters of growth inhibition zones were measured in $\mathrm{mm}$ depending on diameter and clarity.

5.2. Agar Dilution Method. In this method the antifungal activity of $250 \mathrm{ppm}$ of some selected compounds in DMSO was screened against Aspergillus niger. $2.5 \mathrm{~cm}^{3}$ of $2000 \mathrm{ppm}$ of tested solution was added to $20 \mathrm{~cm}^{3}$ of hot agar solution. The homogenized mixture was then poured into petridish and left to solidify. The Aspergillus colony ( $9 \mathrm{~mm}$ diameter) was fixed on the solidified agar, and the medium was incubated at $37^{\circ} \mathrm{C}$ for 8 days.

\section{Results and Discussion}

The IR spectra showed that the three ligands exhibited vibrational modes of $\nu_{\mathrm{C}=\mathrm{N}}$ of azomethine group [4, 6, 26$28],\left(v_{\mathrm{C}-\mathrm{N}}, \delta_{\mathrm{NH}}\right),\left(\nu_{\mathrm{C}-\mathrm{N}}, v_{\mathrm{C}-\mathrm{S}}\right), \nu_{\mathrm{C}-\mathrm{S}}$, and $\nu_{\mathrm{C}=\mathrm{S}}$ of dto moiety $[29,30]$ (Table 1). Spectra of $\mathrm{L}_{\mathrm{I}}$ and $\mathrm{L}_{\mathrm{II}}$ showed vibrational bands related to stretching modes of $\mathrm{OH}$ groups $[31,32]$. The position of the bands assigned to $\nu_{\mathrm{NH}}$ vibrations of the cyclic rings was dependent on their environment. $\nu_{\mathrm{NH}}$ of $\mathrm{L}_{\text {II }}$ and $\mathrm{L}_{\text {III }}$ were observed at lower frequencies compared with that of $\mathrm{L}_{\mathrm{I}}$ (Table 1) $[27,32]$. The latter exhibited bands assigned to $v_{\mathrm{C}=\mathrm{O}}$ and $\nu_{\mathrm{NH}}$ of amide and lactam rings $[6,27$, $31,32]$. The spectra of $\mathrm{L}_{\mathrm{I}}$ complexes with $\mathrm{Co}(\mathrm{II}), \mathrm{Cu}(\mathrm{II})$, and $\mathrm{Pd}(\mathrm{II})$ ions exhibited shift in $\nu_{\mathrm{OH}}$ and $\nu_{\mathrm{C}=\mathrm{N}}$ (azomethine) vibrations. The latter two complexes together with $\mathrm{Ni}(\mathrm{II})$ complex showed additional shifts in $\nu_{\mathrm{NH}}$ to lower frequencies while no significant changes were observed on vibrational modes of $\mathrm{C}=\mathrm{O}$ group which rules out coordination with carbonyl oxygen. Shifts of thioamide bands (III and IV) were observed in the spectra of $\mathrm{Cu}(\mathrm{II})$ and $\mathrm{Pt}(\mathrm{IV})$ complexes and were attributed to coordination of metal ion with sulfur atom [33]. Metal complexes of $\mathrm{L}_{\mathrm{II}}$ showed bands assigned to $\nu_{\mathrm{C}=\mathrm{O}}$ and $\nu_{\mathrm{NH} 2}$ vibrations (Table 1 ). This may be attributed to cleavage of thioamide ring on complexation leading reappearance of $\nu_{\mathrm{C}=\mathrm{O}}$ and $\nu_{\mathrm{NH} 2}$ of both C-2 and $\mathrm{NH}_{2}$ of isatin and dto moieties, respectively. Shifts in $\nu_{\mathrm{NH} 2}$ (compared with $\nu_{\mathrm{NH} 2}$ of the free dto $\left(3296,3203 \mathrm{~cm}^{-1}\right)$ ) [34] to lower frequencies were observed in all spectra of complexes except that of $\mathrm{Ni}$ (II) which was shifted to higher frequency. Bands related to $\nu_{\mathrm{C}=\mathrm{O}}$ vibrations in spectra of both $\mathrm{Ni}(\mathrm{II})$ and $\mathrm{Cu}(\mathrm{II})$ complexes were shifted to higher frequencies while spectra of the other complexes showed shifts to lower frequencies. Additional shifts were observed in the bands assigned to $v_{\mathrm{C}=\mathrm{N}}$ (azomethine) in all complexes except that of $\mathrm{Cu}(\mathrm{II})$. The latter complex exhibited shift of $v_{\mathrm{C}=\mathrm{S}}$ band to lower frequency which refers to coordination of sulfur to $\mathrm{Cu}$ (II) ion [33]. The spectra of $\mathrm{L}_{\mathrm{III}}$ metal complexes exhibited shifts in vibrational modes of $\nu_{\mathrm{C}=\mathrm{O}}$ and band
IV of thioamide group as a result of coordination with metal ions [33, 35]. Additional shift in position of bands assigned to $v_{\mathrm{C}=\mathrm{N}}$ was observed in the spectra of $\mathrm{Co}(\mathrm{II})$ and $\mathrm{Ni}(\mathrm{II})$ complexes. Shifts in the position of $\nu_{\mathrm{NH}}$ amide and $\nu_{\mathrm{C}=\mathrm{O}}$ of lactam ring were observed in the spectra of the $\mathrm{Pd}(\mathrm{II})$ complex as a result of coordination. Bands related to vibrational modes of lattice solvent, coordinated water were observed at $3500-3400 \mathrm{~cm}^{-1}$ [36-38]. Bands appeared at lower frequencies were refered to $\mathrm{M}-\mathrm{O}, \mathrm{M}-\mathrm{N}, \mathrm{M}-\mathrm{S}$, and $\mathrm{M}-\mathrm{Cl}$ stretching modes [36-38]. Further data are collected in (Table 1).

The electronic spectra of $\mathrm{L}_{\mathrm{I}}, \mathrm{L}_{\mathrm{II}}$, and $\mathrm{L}_{\mathrm{III}}$ exhibited highintensity multiple bands in DMF and DMSO at 36231$20000 \mathrm{~cm}^{-1}$. These bands were assigned to $\pi \rightarrow \pi^{*}$ transition of conjugated system. $\mathrm{L}_{\text {III }}$ exhibited additional low-intensity band which was assigned to $\mathrm{n} \rightarrow \pi^{*}$ transition. Changes in positions and profile $\left(\mathrm{C}_{8}-\mathrm{C}_{10}\right)$ of bands were observed in the spectra of metal complexes. Bands related to the (CT) transition were observed as a shoulder on the ligand band in the spectra of $\mathrm{C}_{1}$, $\mathrm{C}_{3}, \mathrm{C}_{6}, \mathrm{C}_{7}, \mathrm{C}_{9}$, and $\mathrm{C}_{10}$ complexes (Table 2). The bands observed in the spectra of $\mathrm{Co}$ (II) complexes in the visible region were assigned to ${ }^{4} \mathrm{~A}_{2} \rightarrow{ }^{4} \mathrm{~T}_{2}\left(\nu_{1}\right),{ }^{4} \mathrm{~A}_{2} \rightarrow{ }^{4} \mathrm{~T}_{1}(\mathrm{~F})\left(\nu_{2}\right)$, and ${ }^{4} \mathrm{~A}_{2} \rightarrow{ }^{4} \mathrm{~T}_{1}(\mathrm{P})\left(\nu_{3}\right)$. The magnetic moment values of $\mathrm{Co}(\mathrm{II})$ complexes were in the range of (3.959-4.6 BM) (Table 2). This indicates tetrahedral geometry around $\mathrm{Co}$ (II) ions [3639] (Scheme 3). The $\mathrm{Ni}(\mathrm{II})$ complex $\mathrm{C}_{2}$ gave a greenish yellow colour in DMF indicating the exchange of weak ligand atoms with solvent molecules [40-43]. The spectrum of this complex showed bands characteristic of octahedral Ni(II) complex [36-38, 40-43] (Table 2), while the other Ni(II) complexes $\left(\mathrm{C}_{7}\right.$ and $\left.\mathrm{C}_{12}\right)$ showed tetrahedral geometries (Scheme 3).

The electronic spectra and magnetic moments ( $\mu_{\text {eff }}$ B.M) (Table 2) of these complexes were consistent with these assignment [36-38, 40-43]. Spectral data $\left(\mathrm{B}^{\prime}, \mathrm{Dq} / \mathrm{B}^{\prime}, 10 \mathrm{Dq}\right.$ and $\beta$ ) (Table 2), for the $\mathrm{Co}(\mathrm{II})$ and $\mathrm{Ni}$ (II) complexes were calculated by applying band energies on Tanaba Saugano diagrams. The energy of $v_{1}$ for $\mathrm{Co}$ (II) complexes $\left(\mathrm{C}_{1}, \mathrm{C}_{6}, \mathrm{C}_{11}\right)$ and $\mathrm{Ni}(\mathrm{II})$ complexes $\left(\mathrm{C}_{7}, \mathrm{C}_{12}\right)$ and $\nu_{3}$ for $\mathrm{Ni}(\mathrm{II})$ complex $\mathrm{C}_{2}$ were also calculated from the diagrams. The spectrum of the $\mathrm{Cu}(\mathrm{II})$ complex $\mathrm{C}_{3}$ exhibited three bands (Table 2) attributed to the spin allowed transitions ${ }^{2} \mathrm{~B}_{1} \mathrm{~g} \rightarrow{ }^{2} \mathrm{~A}_{1} \mathrm{~g}\left(\nu_{1}\right)$, ${ }^{2} \mathrm{~B}_{1} \mathrm{~g} \rightarrow{ }^{2} \mathrm{~B}_{2} \mathrm{~g}\left(\nu_{2}\right)$ and ${ }^{2} \mathrm{~B}_{1} \mathrm{~g} \rightarrow{ }^{2} \mathrm{Eg}\left(\nu_{3}\right)$ of Jahn Teller tetragonally distorted octahedral $\mathrm{Cu}(\mathrm{II})$ complexes [34]. The magnetic moment of the complex (2.36 B.M) indicated paramagnetic character with a high spin orbital coupling [40-43]. The spectrum of $\mathrm{Cu}(\mathrm{II})$ complex $\mathrm{C}_{8}$ exhibited two bands (Table 2) which were assigned to ${ }^{2} \mathrm{~B}_{1} \mathrm{~g} \rightarrow{ }^{2} \mathrm{~A}_{1} \mathrm{~g}\left(\nu_{1}\right)$, and ${ }^{2} \mathrm{~B}_{1} \mathrm{~g} \rightarrow{ }^{2} \mathrm{~B}_{2} \mathrm{~g}\left(\nu_{2}\right)$. These bands were attributed to square planar $\mathrm{Cu}$ (II) complexes [44] (Scheme 3). Magnetic moment $\left(\mu_{\text {eff }}=1.84\right.$ B.M $)$ of the complex supported such conclusion $[36-38,44]$. The spectra of the diamagnetic $\mathrm{Pd}(\mathrm{II})$ complexes $\left(\mathrm{C}_{4}, \mathrm{C}_{9}\right.$, and $\left.\mathrm{C}_{13}\right)$ showed two bands assigned to ${ }^{1} \mathrm{~A}_{1} \mathrm{~g} \rightarrow{ }^{1} \mathrm{~A}_{2} \mathrm{~g}\left(\nu_{1}\right)$ and ${ }^{1} \mathrm{~A}_{1} \mathrm{~g} \rightarrow{ }^{1} \mathrm{~B}_{1} \mathrm{~g}\left(\nu_{2}\right)$ and the additional band ${ }^{1} \mathrm{~A}_{1} \mathrm{~g} \rightarrow{ }^{1} \mathrm{Eg}\left(\nu_{3}\right)$ for $\mathrm{C}_{4}$. These bands are attributed to square planar $\mathrm{Pd}(\mathrm{II})$ complexes [34-38, 40-43]. The spectra of the diamagnetic $\mathrm{Pt}(\mathrm{IV})$ complexes exhibited two bands which were assigned to forbidden transitions 
TABLE 1: FTIR vibrations for the ligands and their metal complexes.

(a)

\begin{tabular}{|c|c|c|c|c|c|c|c|c|c|c|c|}
\hline \multirow{3}{*}{ Symbol } & \multirow{3}{*}{$\nu_{\mathrm{OH}}$} & \multicolumn{10}{|c|}{ Thioamide } \\
\hline & & $\nu_{\mathrm{N}-\mathrm{H}}$ & $\nu_{\mathrm{C}=\mathrm{O}}$ & $\nu_{\mathrm{C}=\mathrm{N}}$ & Band I & Band II & Band III & Band IV & $\nu_{\mathrm{M}-\mathrm{O}}$ & $\nu_{\mathrm{M}-\mathrm{N}}$ & $\nu_{\mathrm{M}-\mathrm{Cl}}$ \\
\hline & & & & & $v_{\mathrm{C}-\mathrm{N}}+\delta_{\mathrm{NH}}$ & $v_{\mathrm{C}-\mathrm{N}}+v_{\mathrm{C}-\mathrm{S}}$ & $\nu_{\mathrm{C}-\mathrm{S}}$ & $\nu_{\mathrm{C}=\mathrm{S}}$ & & & \\
\hline $\mathrm{L}_{\mathrm{I}}$ & 3400 & 3298 & 1710 & 1650 & 1540 & 1465 & 1170 & 881 & - & - & - \\
\hline $\begin{array}{l}\mathrm{C}_{\mathrm{la}} \\
\mathrm{Co}(\mathrm{II})\end{array}$ & 3344 & 3295 & 1718 & 1631 & 1545 & 1460 & 1162 & 877 & 559 & 389 & $277^{*}$ \\
\hline $\begin{array}{l}\mathrm{C}_{1 \mathrm{~b}} \\
\mathrm{Co}(\mathrm{II})\end{array}$ & 3350 & 3295 & 1718 & 1631 & 1545 & 1460 & 1165 & 877 & 559 & 389 & $277^{*}$ \\
\hline $\begin{array}{l}\mathrm{C}_{2} \\
\mathrm{Ni}(\mathrm{II})\end{array}$ & 3402 & 3227 & 1706 & 1631 & 1540 & 1396 & 1165 & 880 & - & 335 & 320 \\
\hline $\begin{array}{l}\mathrm{C}_{3} \\
\mathrm{Cu}(\mathrm{II})\end{array}$ & 3347 & 3260 & 1716 & 1627 & 1520 & 1450 & 1150 & 780 & 408 & 350 & 339 \\
\hline $\begin{array}{l}\mathrm{C}_{4} \\
\mathrm{Pd}(\mathrm{II})\end{array}$ & 3395 & 3250 & 1720 & 1630 & 1573 & 1458 & 1170 & 889 & 586 & 350 & 331 \\
\hline $\begin{array}{l}\mathrm{C}_{5} \\
\mathrm{Pt}(\mathrm{IV})\end{array}$ & 3400 & 3295 & 1715 & 1666 & 1510 & 1483 & 1134 & 850 & - & 340 & 300 \\
\hline
\end{tabular}

Lattice butanol, $\mathrm{C}_{2}, \mathrm{C}_{3}=3500,3750 \mathrm{~cm}^{-1}$, Lattice ethanol, $\mathrm{C}_{5}=3495 \mathrm{~cm}^{-1}$ Coord $\cdot \mathrm{H}_{2} \mathrm{O}, \mathrm{C}_{3}=3456,750,675 ;$ Lattice $\mathrm{H}_{2} \mathrm{O}, \mathrm{C}_{5}=3425 \mathrm{~cm}^{-1} \nu_{\mathrm{M}-\mathrm{S}}, \mathrm{C}_{3}$ and $\mathrm{C}_{5}$ $=345$ and $370 \mathrm{~cm}^{-1}$ respectively, ${ }^{*}$ bridging.

(b)

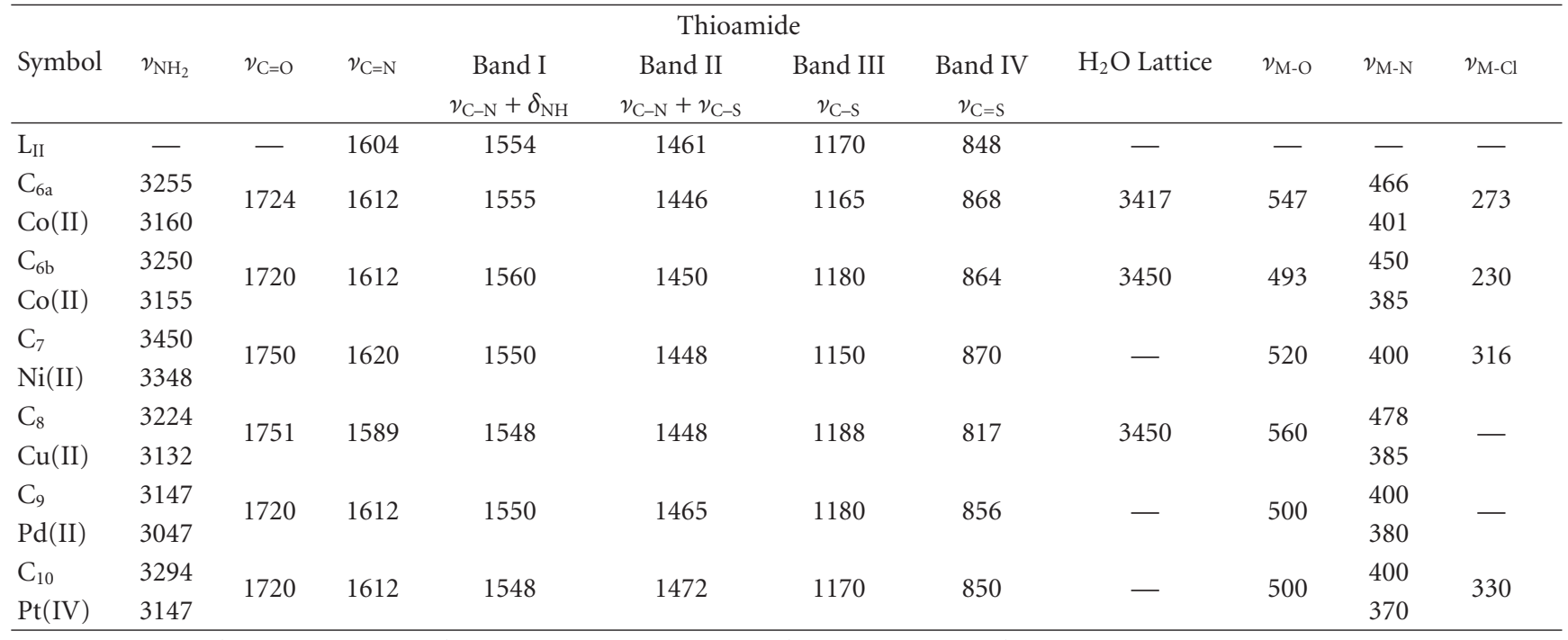

$v_{\mathrm{OH}}, \mathrm{L}_{\mathrm{II}}=3400 \mathrm{~cm}^{-1} ; v_{\mathrm{NH}}, \mathrm{L}_{\mathrm{II}}=3145 \mathrm{~cm}^{-1} ;$ Lattice butanol, $\mathrm{C}_{6 \mathrm{~b}}=3550 \mathrm{~cm}^{-1} v_{\mathrm{M}-\mathrm{S}}, \mathrm{C}_{8}=320 \mathrm{~cm}^{-1}$.

(c)

\begin{tabular}{|c|c|c|c|c|c|c|c|c|c|c|c|c|}
\hline \multirow[b]{2}{*}{ Symbol } & \multirow[b]{2}{*}{$\nu_{\mathrm{N}-\mathrm{H}}$ amide } & \multirow[b]{2}{*}{$\nu_{\mathrm{C}=\mathrm{O}}$ amide } & \multirow[b]{2}{*}{$v_{\mathrm{N}-\mathrm{H}}$ lactam } & \multicolumn{9}{|c|}{ Thioamide group } \\
\hline & & & & $v_{\mathrm{C}=\mathrm{O}}$ lactam & $\nu_{c=N}$ & $\begin{array}{c}\text { Band I } \\
\nu_{\mathrm{C}-\mathrm{N}}+\delta_{\mathrm{NH}}\end{array}$ & $\begin{array}{c}\text { Band II } \\
v_{\mathrm{C}-\mathrm{N}}+v_{\mathrm{C}-\mathrm{S}}\end{array}$ & $\begin{array}{c}\text { Band III } \\
v_{\mathrm{C}-\mathrm{S}}\end{array}$ & $\begin{array}{c}\text { Band IV } \\
v_{\mathrm{C}=\mathrm{S}}\end{array}$ & $\nu_{\mathrm{M}-\mathrm{O}}$ & $v_{\mathrm{M}-\mathrm{N}}$ & $v_{\mathrm{M}-\mathrm{S}}$ \\
\hline $\mathrm{L}_{\mathrm{III}}$ & 3394 & 1635 & 3247 & 1674 & 1600 & 1535 & 1465 & 1103 & 880 & - & - & - \\
\hline $\begin{array}{l}\mathrm{C}_{11 \mathrm{a}} \\
\mathrm{Co}(\mathrm{II})\end{array}$ & 3410 & 1625 & 3247 & 1674 & 1587 & 1535 & 1450 & 1095 & 830 & 590 & 480 & 320 \\
\hline $\begin{array}{l}\mathrm{C}_{11 \mathrm{~b}} \\
\mathrm{Co}(\mathrm{II})\end{array}$ & 3410 & 1620 & 3247 & 1674 & 1580 & 1535 & 1450 & 1100 & 840 & 600 & 480 & 300 \\
\hline $\begin{array}{l}\mathrm{C}_{12} \\
\mathrm{Ni}(\mathrm{II})\end{array}$ & 3456 & 1625 & 3250 & 1670 & 1589 & 1535 & 1450 & 1100 & 860 & 580 & 450 & 308 \\
\hline $\begin{array}{l}\mathrm{C}_{13} \\
\mathrm{Pd}(\mathrm{II})\end{array}$ & 3386 & 1620 & 3250 & 1666 & 1600 & 1535 & 1473 & 1095 & 850 & 617 & 401 & 310 \\
\hline
\end{tabular}

Lattic $\mathrm{H}_{2} \mathrm{O}, \mathrm{C}_{11 \mathrm{a}}, \mathrm{C}_{11 \mathrm{~b}}=3500 \mathrm{~cm}^{-1}$ 
TABLE 2: Electronic spectra, spectral parameters and magnetic moment with suggested structures of $\mathrm{L}_{\mathrm{I}}, \mathrm{L}_{\mathrm{II}}$, and $\mathrm{L}_{\mathrm{III}}$ complexes.

\begin{tabular}{|c|c|c|c|c|c|c|c|c|}
\hline Symbol & $\begin{array}{l}\text { Band positions } \\
\left(\mathrm{cm}^{-1}\right)\end{array}$ & Assignment & $\mathrm{Dq} / \overline{\mathrm{B}}(\beta)$ & $\overline{\mathrm{B}}\left(\mathrm{cm}^{-1}\right)$ & $10 \mathrm{Dq}\left(\mathrm{cm}^{-1}\right)$ & $\mu_{\text {eff }}($ B.M $)$ & $\begin{array}{l}\text { Suggested } \\
\text { structure }\end{array}$ & $\begin{array}{l}\text { Molar conductivity } \\
\mathrm{S} \cdot \mathrm{mol}^{-1} \cdot \mathrm{cm}^{2} \text { in } \\
\text { DMF and DMSO* }\end{array}$ \\
\hline $\begin{array}{l}\mathrm{C}_{1 \mathrm{a}} \\
\mathrm{Co}(\mathrm{II})\end{array}$ & $\begin{array}{l}v_{1} 6388 \text { (cal.) } \\
v_{2} 10752 \\
v_{3} 16930 \text { (avr.) } \\
v_{4} 21008\end{array}$ & $\begin{array}{l}{ }^{4} \mathrm{~A}_{2} \rightarrow{ }^{4} \mathrm{~T}_{2} \\
{ }^{4} \mathrm{~A}_{2} \rightarrow{ }^{4} \mathrm{~T}_{1}(\mathrm{~F}) \\
{ }^{4} \mathrm{~A}_{2} \rightarrow{ }^{4} \mathrm{~T}_{1}(\mathrm{P}) \\
\mathrm{L} \rightarrow \mathrm{M}(\mathrm{C} . \mathrm{T})\end{array}$ & $\begin{array}{c}1.3 \\
(0.484)\end{array}$ & 470.2 & 6112 & 4.5 & Tetrahedral & $32.12^{*}$ \\
\hline $\begin{array}{l}\mathrm{C}_{\mathrm{lb}} \\
\mathrm{Co}(\mathrm{II})\end{array}$ & $\begin{array}{l}v_{1} 6388 \text { (cal.) } \\
v_{2} 10752 \\
v_{3} 16930 \text { (avr.) } \\
v_{4} 21881\end{array}$ & $\begin{array}{l}{ }^{4} \mathrm{~A}_{2} \rightarrow{ }^{4} \mathrm{~T}_{2} \\
{ }^{4} \mathrm{~A}_{1} \rightarrow{ }^{4} \mathrm{~T}_{1}(\mathrm{~F}) \\
{ }^{4} \mathrm{~A}_{2} \rightarrow{ }^{4} \mathrm{~T}_{1}(\mathrm{P}) \\
\mathrm{L} \rightarrow \mathrm{M}(\mathrm{C} . \mathrm{T})\end{array}$ & $\begin{array}{c}1.3 \\
(0.484)\end{array}$ & 470.2 & 6112 & 4.61 & Tetrahedral & $29.7^{*}$ \\
\hline $\begin{array}{l}\mathrm{C}_{2} \\
\mathrm{Ni}(\mathrm{II})\end{array}$ & $\begin{array}{l}v_{1} 12345 \\
v_{2} 16806 \\
v_{3} 27035 \text { (cal.) }\end{array}$ & $\begin{array}{l}{ }^{3} \mathrm{~A}_{2} \mathrm{~g} \rightarrow{ }^{3} \mathrm{~T}_{2} \mathrm{~g} \\
{ }^{3} \mathrm{~A}_{2} \mathrm{~g} \rightarrow{ }^{3} \mathrm{~T}_{1} \mathrm{~g}(\mathrm{~F}) \\
{ }^{3} \mathrm{~A}_{2} \mathrm{~g} \rightarrow{ }^{3} \mathrm{~T}_{1} \mathrm{~g}(\mathrm{P})\end{array}$ & $\begin{array}{c}2.8 \\
(0.440)\end{array}$ & 454.2 & 12717 & 3.31 & Octahedral & 46.45 \\
\hline $\begin{array}{l}\mathrm{C}_{3} \\
\mathrm{Cu}(\mathrm{II})\end{array}$ & $\begin{array}{l}v_{1} 12150 \\
v_{2} 16666 \\
v_{3} 18761 \\
v_{4} 19646\end{array}$ & $\begin{array}{l}{ }^{2} \mathrm{~B}_{1} \mathrm{~g} \rightarrow{ }^{2} \mathrm{~A}_{1} \mathrm{~g} \\
{ }^{2} \mathrm{~B}_{1} \mathrm{~g} \rightarrow{ }^{2} \mathrm{~B}_{2} \mathrm{~g} \\
{ }^{2} \mathrm{~B}_{1} \mathrm{~g} \rightarrow{ }^{2} \mathrm{Eg} \\
\mathrm{L} \rightarrow \mathrm{M}(\mathrm{C} . \mathrm{T})\end{array}$ & & & & 2.36 & Octahedral & 68.19 \\
\hline $\begin{array}{l}\mathrm{C}_{4} \\
\mathrm{Pd}(\mathrm{II})\end{array}$ & $\begin{array}{l}v_{1} 12048 \\
v_{2} 16949 \\
v_{3} 20618\end{array}$ & $\begin{array}{l}{ }^{1} \mathrm{~A}_{1} \mathrm{~g} \rightarrow{ }^{1} \mathrm{~A}_{2} \mathrm{~g} \\
{ }^{1} \mathrm{~A}_{1} \mathrm{~g} \rightarrow{ }^{1} \mathrm{~B}_{1} \mathrm{~g} \\
{ }^{1} \mathrm{~A}_{1} \mathrm{~g} \rightarrow{ }^{1} \mathrm{Eg}\end{array}$ & & & & Diamagnetic & $\begin{array}{l}\text { Square } \\
\text { planar }\end{array}$ & 60.37 \\
\hline $\begin{array}{l}\mathrm{C}_{5} \\
\mathrm{Pt}(\mathrm{IV})\end{array}$ & $\begin{array}{l}v_{1} 17825 \\
v_{2} 22371\end{array}$ & $\begin{array}{l}{ }^{1} \mathrm{~A}_{1} \mathrm{~g} \rightarrow{ }^{3} \mathrm{~T}_{1} \mathrm{~g}(\mathrm{H}) \\
{ }^{1} \mathrm{~A}_{1} \mathrm{~g} \rightarrow{ }^{3} \mathrm{~T}_{2} \mathrm{~g}\end{array}$ & & & & Diamagnetic & Octahedral & 154.13 \\
\hline $\begin{array}{l}\mathrm{C}_{6 \mathrm{a}} \\
\mathrm{Co}(\mathrm{II})\end{array}$ & $\begin{array}{l}v_{1} 6535 \text { (cal.) } \\
v_{2} 10526 \\
v_{3} 16666 \\
v_{4} 21551\end{array}$ & $\begin{array}{l}{ }^{4} \mathrm{~A}_{2} \rightarrow{ }^{4} \mathrm{~T}_{2} \\
{ }^{4} \mathrm{~A}_{2} \rightarrow{ }^{4} \mathrm{~T}_{1} \\
{ }^{4} \mathrm{~A}_{2} \rightarrow{ }^{4} \mathrm{~T}_{1}(\mathrm{P}) \\
\mathrm{L} \rightarrow \mathrm{M}(\mathrm{C} . \mathrm{T})\end{array}$ & $\begin{array}{c}1.25 \\
(0.501)\end{array}$ & 487.3 & 6091 & 4.21 & Tetrahedral & $34.3^{*}$ \\
\hline $\begin{array}{l}\mathrm{C}_{6 \mathrm{~b}} \\
\mathrm{Co}(\mathrm{II})\end{array}$ & $\begin{array}{l}v_{1} 6389 \text { (cal.) } \\
v_{2} 10504 \\
v_{3} 16612 \\
v_{4} 20876\end{array}$ & $\begin{array}{l}{ }^{4} \mathrm{~A}_{2} \rightarrow{ }^{4} \mathrm{~T}_{2} \\
{ }^{4} \mathrm{~A}_{2} \rightarrow{ }^{4} \mathrm{~T}_{1}(\mathrm{~F}) \\
{ }^{4} \mathrm{~A}_{2} \rightarrow{ }^{4} \mathrm{~T}_{1}(\mathrm{P}) \\
\mathrm{L} \rightarrow \mathrm{M}(\mathrm{C} . \mathrm{T})\end{array}$ & $\begin{array}{c}1.25 \\
(0.503)\end{array}$ & 488.5 & 6107 & 4.30 & Tetrahedral & $30.52^{*}$ \\
\hline $\begin{array}{l}\mathrm{C}_{7} \\
\mathrm{Ni}(\mathrm{II})\end{array}$ & $\begin{array}{l}v_{1} 5473 \text { (cal.) } \\
v_{2} 11074 \\
v_{3} 15873 \\
v_{4} 18867\end{array}$ & $\begin{array}{l}{ }^{3} \mathrm{~T}_{1}(\mathrm{~F}) \rightarrow{ }^{3} \mathrm{~T}_{2}(\mathrm{~F}) \\
{ }^{3} \mathrm{~T}_{1}(\mathrm{~F}) \rightarrow{ }^{3} \mathrm{~A}_{2}(\mathrm{~F}) \\
{ }^{3} \mathrm{~T}_{1}(\mathrm{~F}) \rightarrow{ }^{3} \mathrm{~T}_{1}(\mathrm{P}) \\
\mathrm{L} \rightarrow \mathrm{M}(\mathrm{C} . \mathrm{T})\end{array}$ & $\begin{array}{c}0.82 \\
(0.70)\end{array}$ & 721.5 & 5768 & 2.73 & Tetrahedral & $7.9^{*}$ \\
\hline $\begin{array}{l}\mathrm{C}_{8} \\
\mathrm{Cu}(\mathrm{II})\end{array}$ & $\begin{array}{l}v_{1} 13440 \\
v_{2} 19230\end{array}$ & $\begin{array}{l}{ }^{2} \mathrm{~B}_{1} \mathrm{~g} \rightarrow{ }^{2} \mathrm{~A}_{1} \mathrm{~g} \\
{ }^{2} \mathrm{~B}_{1} \mathrm{~g} \rightarrow{ }^{2} \mathrm{~B}_{2} \mathrm{~g}\end{array}$ & & & & 1.84 & $\begin{array}{l}\text { Square } \\
\text { planar }\end{array}$ & 155.8 \\
\hline
\end{tabular}


TABle 2: Continued.

\begin{tabular}{|c|c|c|c|c|c|c|c|c|}
\hline Symbol & $\begin{array}{l}\text { Band positions } \\
\left(\mathrm{cm}^{-1}\right)\end{array}$ & Assignment & $\mathrm{Dq} / \overline{\mathrm{B}}(\beta)$ & $\overline{\mathrm{B}}\left(\mathrm{cm}^{-1}\right)$ & $10 \mathrm{Dq}\left(\mathrm{cm}^{-1}\right)$ & $\mu_{\text {eff }}($ B.M $)$ & $\begin{array}{l}\text { Suggested } \\
\text { structure }\end{array}$ & $\begin{array}{l}\text { Molar conductivity } \\
\mathrm{S} \cdot \mathrm{mol}^{-1} \cdot \mathrm{cm}^{2} \text { in } \\
\text { DMF and DMSO* }\end{array}$ \\
\hline $\mathrm{C}_{9}$ & $v_{1} 16949$ & ${ }^{1} \mathrm{~A}_{1} \mathrm{~g} \rightarrow{ }^{1} \mathrm{~A}_{2} \mathrm{~g}$ & & & & \multirow{2}{*}{ Diamagnetic } & \multirow{2}{*}{$\begin{array}{l}\text { Square } \\
\text { planar }\end{array}$} & \multirow{2}{*}{125.4} \\
\hline $\mathrm{Pd}(\mathrm{II})$ & $v_{2} 21367$ & ${ }^{1} \mathrm{~A}_{1} \mathrm{~g} \rightarrow{ }^{1} \mathrm{~B}_{1} \mathrm{~g}(\mathrm{C} . \mathrm{T})$ & & & & & & \\
\hline $\mathrm{C}_{10}$ & $v_{1} 14388$ & ${ }^{1} \mathrm{~A}_{1} \mathrm{~g} \rightarrow{ }^{3} \mathrm{~T}_{1} \mathrm{~g}$ & & & & \multirow{2}{*}{ Diamagnetic } & \multirow{2}{*}{ Octahedral } & \multirow{2}{*}{196.6} \\
\hline $\mathrm{Pt}(\mathrm{IV})$ & $\nu_{2} 20576$ & ${ }^{1} \mathrm{~A}_{1} \mathrm{~g} \rightarrow{ }^{3} \mathrm{~T}_{2} \mathrm{~g}(\mathrm{C} . \mathrm{T})$ & & & & & & \\
\hline $\mathrm{C}_{11 \mathrm{a}}$ & $\nu_{1} 6410$ (cal.) & ${ }^{4} \mathrm{~A}_{2} \rightarrow{ }^{4} \mathrm{~T}_{2}$ & 1.5 & & & \multirow{3}{*}{3.959} & \multirow{3}{*}{ Tetrahedral } & \multirow{3}{*}{143.5} \\
\hline \multirow[t]{2}{*}{$\mathrm{Co}(\mathrm{II})$} & $v_{2} 10000$ & ${ }^{4} \mathrm{~A}_{2} \rightarrow{ }^{4} \mathrm{~T}_{1}(\mathrm{~F})$ & $(0.449)$ & 436.8 & 6552 & & & \\
\hline & $v_{3} 15641$ (avr.) & ${ }^{4} \mathrm{~A}_{2} \rightarrow{ }^{4} \mathrm{~T}_{1}(\mathrm{P})$ & & & & & & \\
\hline $\mathrm{C}_{11 \mathrm{~b}}$ & $\nu_{1} 6410$ (cal.) & ${ }^{4} \mathrm{~A}_{2} \rightarrow{ }^{4} \mathrm{~T}_{2}$ & 1.5 & & & \multirow{3}{*}{3.997} & \multirow{3}{*}{ Tetrahedral } & \multirow{3}{*}{150.6} \\
\hline \multirow[t]{2}{*}{$\mathrm{Co}(\mathrm{II})$} & $v_{2} 10000$ & ${ }^{4} \mathrm{~A}_{2} \rightarrow{ }^{4} \mathrm{~T}_{1}(\mathrm{~F})$ & $(0.449)$ & 436.8 & 6552 & & & \\
\hline & $\nu_{3} 15641$ (avr.) & ${ }^{4} \mathrm{~A}_{2} \rightarrow{ }^{4} \mathrm{~T}_{1}(\mathrm{P})$ & & & & & & \\
\hline $\mathrm{C}_{12}$ & $v_{1} 4994$ (cal.) & ${ }^{3} \mathrm{~T}_{1}(\mathrm{~F}) \rightarrow{ }^{3} \mathrm{~T}_{2}(\mathrm{~F})$ & 0.74 & & & \multirow{3}{*}{2.746} & \multirow{3}{*}{ Tetrahedral } & \multirow{3}{*}{159.4} \\
\hline \multirow[t]{2}{*}{$\mathrm{Ni}(\mathrm{II})$} & $v_{2} 10482$ & ${ }^{3} \mathrm{~T}_{1}(\mathrm{~F}) \rightarrow{ }^{3} \mathrm{~A}_{2}(\mathrm{~F})$ & $(0.653)$ & 673.1 & 4980 & & & \\
\hline & $v_{3} 15483$ (avr.) & ${ }^{3} \mathrm{~T}_{1}(\mathrm{~F}) \rightarrow{ }^{3} \mathrm{~T}_{1}(\mathrm{P})$ & & & & & & \\
\hline $\mathrm{C}_{13}$ & $v_{1} 12820$ & ${ }^{1} \mathrm{~A}_{1} \mathrm{~g} \rightarrow{ }^{1} \mathrm{~A}_{2} \mathrm{~g}$ & & & & \multirow{2}{*}{ Diamagnetic } & \multirow{2}{*}{$\begin{array}{l}\text { Square } \\
\text { planar }\end{array}$} & \multirow[t]{2}{*}{148.2} \\
\hline $\mathrm{Pd}(\mathrm{II})$ & $v_{2} 16666$ & ${ }^{1} \mathrm{~A}_{1} \mathrm{~g} \rightarrow{ }^{1} \mathrm{~B}_{1} \mathrm{~g}$ & & & & & & \\
\hline
\end{tabular}

${ }^{1} \mathrm{~A}_{1} \mathrm{~g} \rightarrow{ }^{3} \mathrm{~T}_{1} \mathrm{~g}$ and ${ }^{1} \mathrm{~A}_{1} \mathrm{~g} \rightarrow{ }^{3} \mathrm{~T}_{2} \mathrm{~g}$ showing octahedral geometry around $\mathrm{Pt}(\mathrm{IV})$ ion [40-43] (Scheme 3 ). The molar conductivities (Table 2) showed that electrolytic nature of the $\mathrm{Pt}(\mathrm{IV})$ complex $\left(\mathrm{C}_{10}\right)$ was $1: 3, \mathrm{Pt}(\mathrm{IV}), \mathrm{Cu}(\mathrm{II}), \mathrm{Pd}(\mathrm{II}), \mathrm{Co}(\mathrm{II})$ and $\mathrm{Ni}(\mathrm{II})$ complexes $\left(\mathrm{C}_{5}, \mathrm{C}_{8}, \mathrm{C}_{9}, \mathrm{C}_{11}, \mathrm{C}_{12}\right.$, and $\left.\mathrm{C}_{13}\right) 1$ : 2, and $\mathrm{Co}(\mathrm{II}), \mathrm{Cu}(\mathrm{II})$, and $\mathrm{Pd}(\mathrm{II})$ complexes $\left(\mathrm{C}_{1}, \mathrm{C}_{3}, \mathrm{C}_{4}\right.$, and $\left.\mathrm{C}_{6}\right) 1: 1$, while the $\mathrm{Ni}(\mathrm{II})$ complexes $\left(\mathrm{C}_{2}\right.$ and $\left.\mathrm{C}_{7}\right)$ were nonelectrolyte [45]. From these observations, together with the results obtained from other analytical data, the sterochemical structures of the complexes were suggested (Scheme 3).

Thermogravimetric analyses (TG and DTG) have been studied at heating range of $50-800^{\circ} \mathrm{C}$ for the complexes $\left(\mathrm{C}_{1}, \mathrm{C}_{3}, \mathrm{C}_{4}\right.$, and $\left.\mathrm{C}_{7}\right)$ under nitrogen atmosphere. The following results (Table 3) were explained according to analytical suggestions mentioned in literature [46-48]. (i) Lattice water, free ions, and organic fragments that are not directly coordinated to the metal ions were found to leave the complex at earlier stages compared with coordinated fragments, (ii) The heating range $\left(50-800^{\circ} \mathrm{C}\right)$ produced incomplete decomposition of metal complexes, and the final products were dependent on the type of metal ion and on (M-L) affinity [36-38, 46, 49] which reflects the stability of complexes.

\section{Biological Screening}

The antibacterial activity for precursors, $\mathrm{L}_{\mathrm{I}}$ and $\mathrm{L}_{\mathrm{III}}$, and some of their complexes was evaluated against Staphylococcus aureus $\left(\mathrm{G}^{+}\right)$and Proteus vulgaris $\left(\mathrm{G}^{-}\right)$using the agar diffusion method. Diameter $(\mathrm{mm})$ of growth inhibition zones was measured after incubation for 24 hours at $37^{\circ} \mathrm{C}$. The results showed that no antibacterial action was recorded by the studied compounds using concentration of 150, 350, and $650 \mathrm{ppm}$. Using $1000 \mathrm{ppm}$ (Table 4), $\mathrm{L}_{\mathrm{I}}$ and its complexes were more active against Staphylococcus aureus, while LIII and its complexes (except $\mathrm{C}_{13}$ ) were more active against Proteus vulgaris than the other studied compounds. The antifungal activity was evaluated against Candida albicans by the agar diffusion method and Aspergillus niger colony $(9 \mathrm{~mm}$ diameter) by the agar dilution method using concentration of $250 \mathrm{ppm}$ in DMSO. The results showed that $\mathrm{L}_{\mathrm{I}}$ and $\mathrm{L}_{\text {III }}$ were inactive against Candida albicans; $\mathrm{Co}(\mathrm{II})\left(\mathrm{C}_{11}\right), \mathrm{Ni}(\mathrm{II})$ $\left(\mathrm{C}_{12}\right)$, and $\mathrm{Pd}(\mathrm{II})\left(\mathrm{C}_{13}\right)$ complexes were more active than the parent ligand $\left(\mathrm{L}_{\text {III }}\right)$ while those of $\mathrm{L}_{\mathrm{I}}$ were inactive except $\mathrm{Cu}$ (II) complex $\left(\mathrm{C}_{3}\right) . \mathrm{L}_{\mathrm{I}}, \mathrm{L}_{\mathrm{III}}$, and $\mathrm{C}_{4}$ which were inactive against Candida albicans showed moderate activity against Aspergillus niger which refer to the effective selectivity of specific inhibitor on the microorganisms. 
TABle 3: Thermal decomposition of $\mathrm{C}_{1}, \mathrm{C}_{3}, \mathrm{C}_{4}$, and $\mathrm{C}_{7}$.

(a)

$\mathrm{C}_{1}$

$\left[\left(\mathrm{L}_{\mathrm{I}}\right)_{2} \mathrm{Co}_{2} \mathrm{Cl}_{3}\right] \mathrm{Cl}$

$\mathrm{M} \cdot \mathrm{wt}=841.8$

Temperature range of decomposition ${ }^{\circ} \mathrm{C}$

\%Weight loss found (calc.)

$-2 \mathrm{Cl}$

$-2 \mathrm{ph}$

251-369

$41.128(41.45)$

$-\mathrm{C}_{5} \mathrm{H}_{6} \mathrm{~N}_{2} \mathrm{O}_{2}$

$-\mathrm{OH}$

370-421

$2.798(2.01)$

$-2 \mathrm{Cl}$

$465-547$

$7.932(8.43)$

$-\left(\mathrm{C}_{7} \mathrm{H}_{3} \mathrm{~N}_{4} \mathrm{OS}_{4}\right) 2 \mathrm{Co}$

48.25 (48.08)

(b)

$\mathrm{C}_{3}$

$\left[\mathrm{L}_{\mathrm{I}} \mathrm{CuCl}\left(\mathrm{H}_{2} \mathrm{O}\right)\right] \mathrm{Cl} \cdot 0.5 \mathrm{BuOH}$

$\mathrm{M} \cdot \mathrm{wt}=480.5$

Temperture range of decomposition ${ }^{\circ} \mathrm{C}$

\%Weight loss found (calc.)

$-\mathrm{BuOH}$

$-\mathrm{Cl}$

$-\mathrm{H}_{2} \mathrm{O}$

356-476

$36.592(36.94)$

$-\mathrm{CS}$

$-\mathrm{C}_{2} \mathrm{H}_{3} \mathrm{O}$

$-\mathrm{C}_{2} \mathrm{NS}$

$-\mathrm{NH}$

477-630

$18.008(17.68)$

$-(\mathrm{phCHNO}) \mathrm{CuCl}$

$45.41(45.36)$

(c)

$\mathrm{C}_{4}$

$\left[\left(\mathrm{L}_{\mathrm{I}}\right)_{2} \mathrm{PdCl}\right] \mathrm{Cl}$

$\mathrm{M} \cdot \mathrm{wt}=759$

Temperture range of decomposition ${ }^{\circ} \mathrm{C}$

\%Weight loss found (calc.)

$-2 \mathrm{Cl}$
$-\mathrm{C}_{2} \mathrm{H}_{3} \mathrm{O}$

145-219

$14.925(15.01)$

$-\mathrm{phC}_{3} \mathrm{H}_{4} \mathrm{NO}_{2}$

219-351

$21.189(21.34)$

$-\mathrm{ph}$

482-568

$10.538(10.01)$

$-\mathrm{CN}$

679-735

$3.188(3.42)$

$-\left(\mathrm{C}_{6} \mathrm{H}_{3} \mathrm{~N}_{4} \mathrm{OS}_{4}\right) \mathrm{Pd}$

$50.096(50.197)$

(d)

$\mathrm{C}_{7}$

[L $\left.\mathrm{L}_{\mathrm{II}} \mathrm{NiCl} 2\right]$

$\mathrm{M} \cdot \mathrm{wt}=468.7$

Temperture range of decomposition ${ }^{\circ} \mathrm{C}$

\%Weight loss found (calc.)

$-\mathrm{CO}$

$-\mathrm{NH}_{2}$

50-127

$9.183(9.38)$

$-\mathrm{phCH}_{2}$

239-377

19.672 (19.415)

$-2 \mathrm{Cl}$

432-565

34.42 (34.35)

$-\mathrm{phN}$

$36.858(36.84)$ 

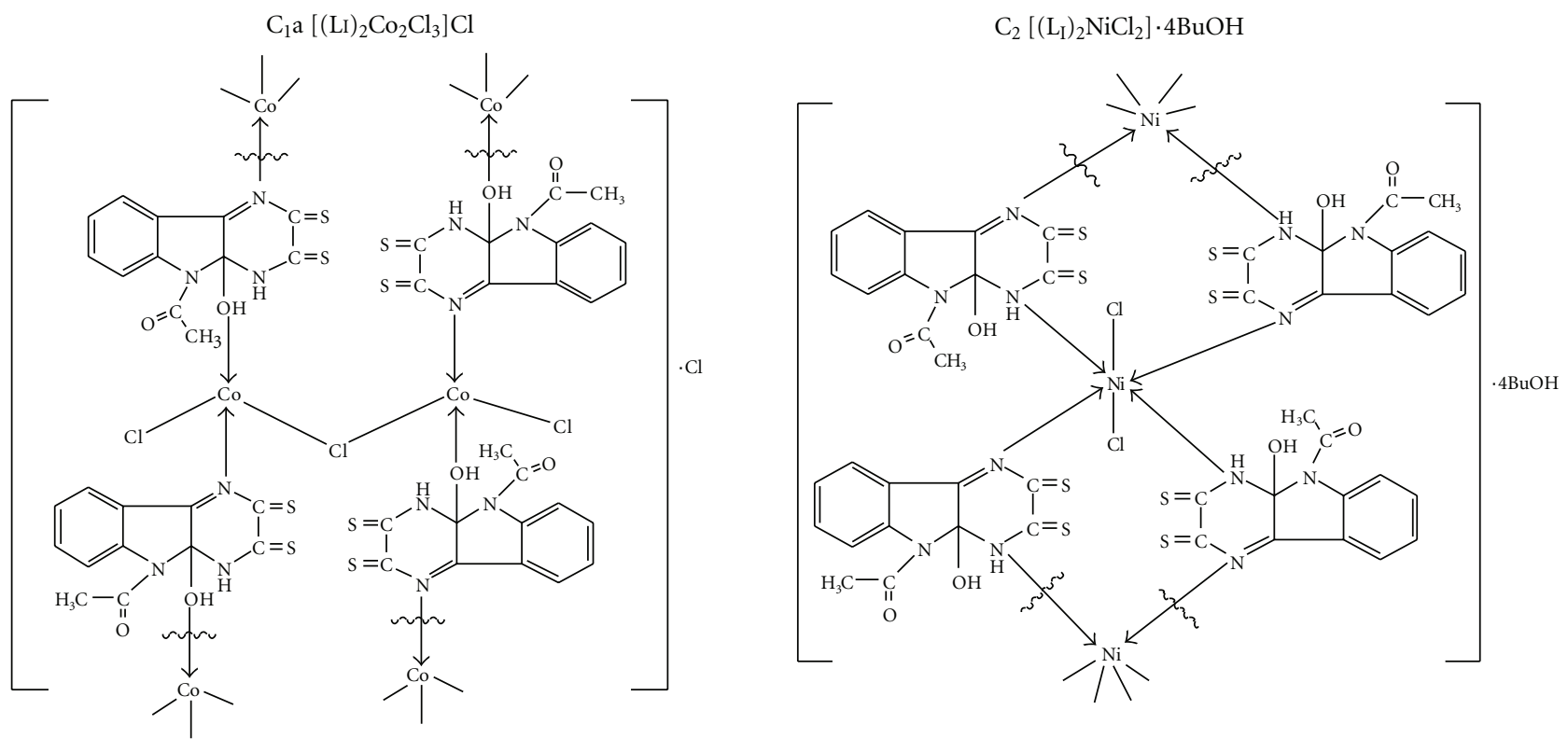

\section{$\mathrm{C}_{3}\left[\mathrm{~L}_{1} \mathrm{CuCl}\left(\mathrm{H}_{2} \mathrm{O}\right)\right] \mathrm{Cl} \cdot 0.5 \mathrm{BuOH}$}
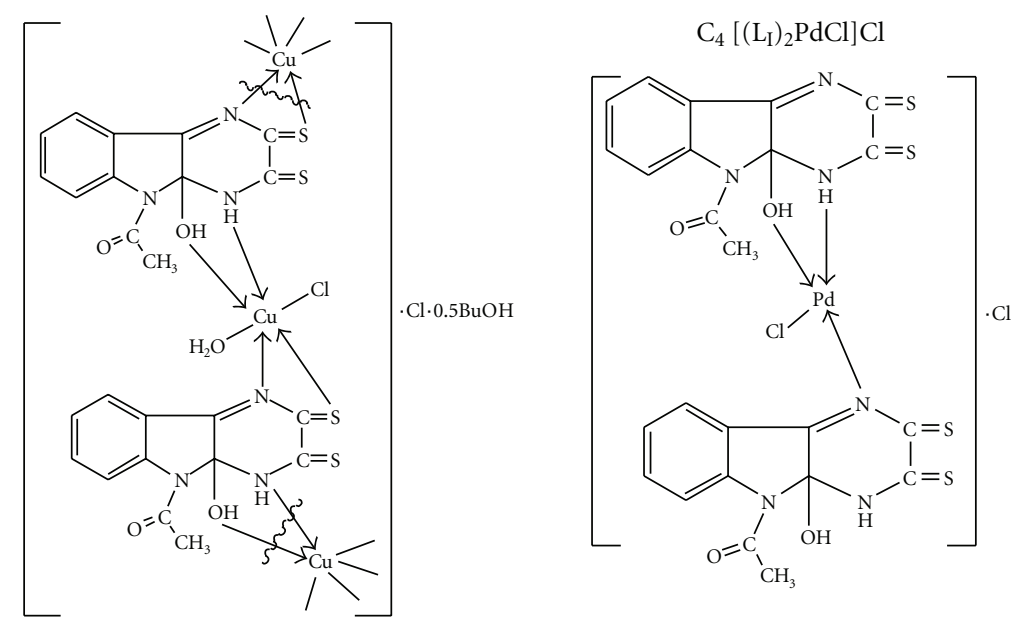

$\mathrm{C}_{5}\left[\left(\mathrm{~L}_{\mathrm{I}}\right)_{2} \mathrm{PtCl}_{2}\right] \mathrm{Cl}_{2} \cdot 1.8 \mathrm{EtOH} \cdot \mathrm{H}_{2} \mathrm{O}$

$\mathrm{C}_{6 \mathrm{a}}\left[\mathrm{L}_{\mathrm{II}} \mathrm{CoCl}\right] \mathrm{Cl} \cdot 0.4 \mathrm{H}_{2} \mathrm{O} \cdot 0.3 \mathrm{DMSO}$

\section{$\mathrm{C}_{8}\left[\mathrm{~L}_{\mathrm{II}} \mathrm{Cu}\right] \mathrm{Cl}_{2} \cdot \mathrm{H}_{2} \mathrm{O}$}
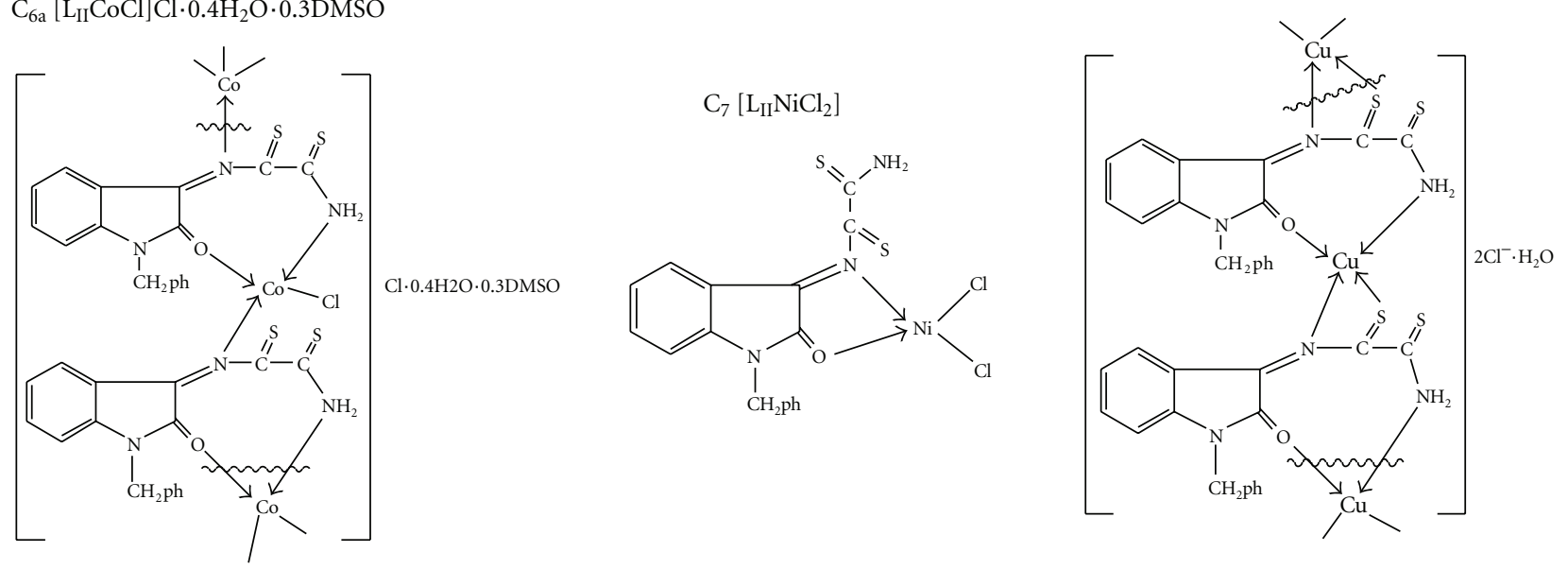

Scheme 3: Continued. 
$\mathrm{C}_{9}\left[\left(\mathrm{~L}_{\mathrm{II}}\right)_{2} \mathrm{Pd}\right] \mathrm{Cl}_{2}$

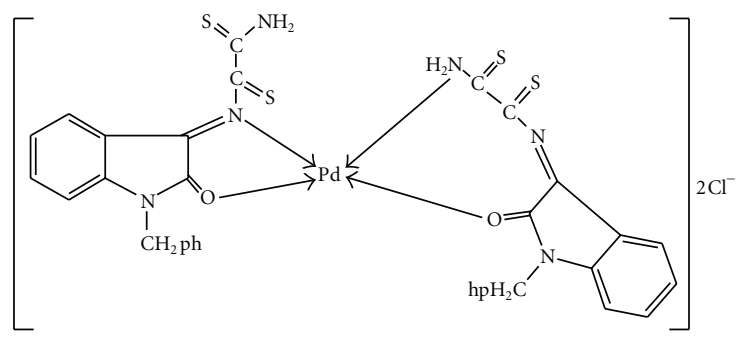

$\mathrm{C}_{10}\left[\left(\mathrm{~L}_{\mathrm{II}}\right)_{2.5} \mathrm{PtCl}\right] \mathrm{Cl}_{3}$

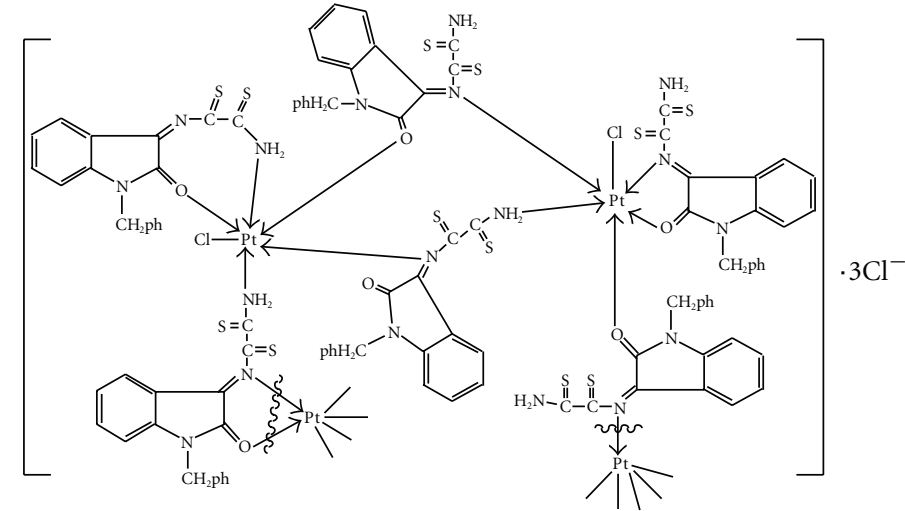

$\mathrm{C}_{12}\left[\left(\mathrm{~L}_{\mathrm{III}}\right)_{2} \mathrm{Ni}\right] \mathrm{Cl}_{2}$

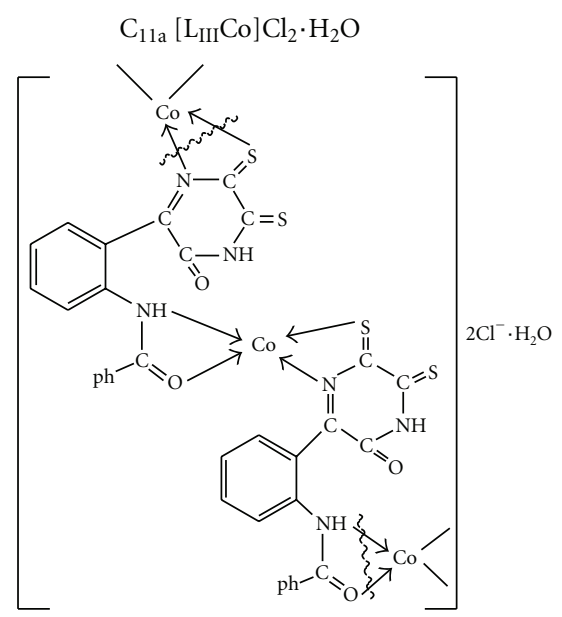

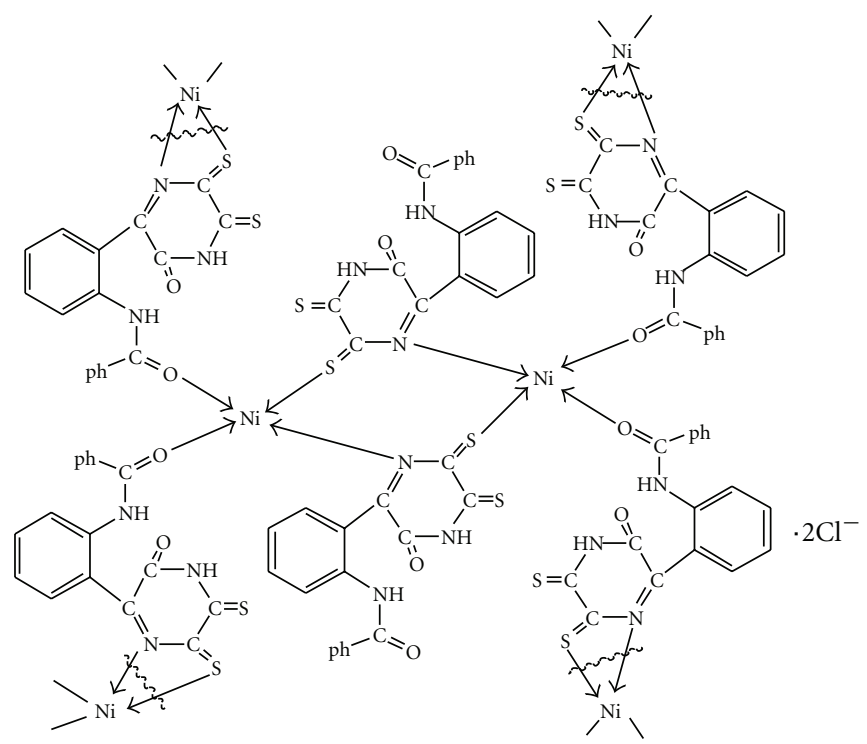

$\mathrm{C}_{13}\left[\left(\mathrm{~L}_{\mathrm{III}}\right)_{2} \mathrm{Pd}\right] \mathrm{Cl}_{2}$

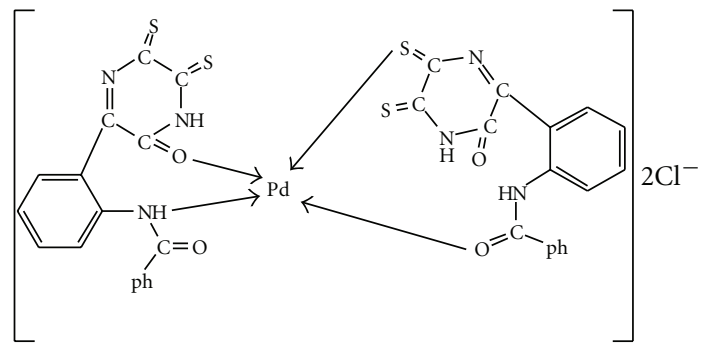

Scheme 3: Suggested structures of studied compounds.

\section{Conclusions}

(1) Condensation reaction of N-acetyl, N-benzyl, and $\mathrm{N}$-benzoyl isatins with dto gave Schiff base ligands $\mathrm{L}_{\mathrm{I}}-\mathrm{L}_{\mathrm{III}}$, as was confirmed by ${ }^{1} \mathrm{H},{ }^{13} \mathrm{C} \mathrm{NMR}$, and IR spectra.
(2) The formation of the Schiff base ligand $\mathrm{L}_{\text {III }}$ took place with ring cleavage at C-2 of the heterocyclic ring of the benzoylisatin. Whereas the formation of $\mathrm{L}_{I}$ and $\mathrm{L}_{\text {II }}$ took place without ring cleavage.

(3) The presence of various donor atoms and the stereochemistry of the studied ligands enhanced different 
TABle 4: Antibacterial and Antifungal activities of studied compounds.

\begin{tabular}{|c|c|c|c|c|}
\hline Compounds & $\begin{array}{l}\text { Staphylococcus aureus inhibition } \\
\text { diameter }(\mathrm{mm}) 1000 \mathrm{ppm}\end{array}$ & $\begin{array}{l}\text { Proteus vulgris inhibition } \\
\text { diameter }(\mathrm{mm}) 1000 \mathrm{ppm}\end{array}$ & $\begin{array}{c}\text { Candida albecans inhibition } \\
\text { diameter }(\mathrm{mm}) 1000 \mathrm{ppm}\end{array}$ & $\begin{array}{l}\text { Aspergillus niger growth } \\
\text { diameter }(\mathrm{mm}) 1000 \mathrm{ppm}\end{array}$ \\
\hline DMSO & Zero & Zero & Zero & 25 \\
\hline Isatin & 3 & 8 & 6 & \\
\hline $\mathrm{N}$-acetylisatin & 4 & Zero & 5 & \\
\hline N-benzylisatin & 5 & 5 & 6 & \\
\hline N-benzoylisatin & 5 & 5 & Zero & \\
\hline $\mathrm{L}_{\mathrm{I}}$ & 8 & 5 & Zero & 9 \\
\hline $\mathrm{C}_{2}(\mathrm{Ni}(\mathrm{II}))$ & 4 & 8 & Zero & \\
\hline $\mathrm{C}_{3}(\mathrm{Cu}(\mathrm{II}))$ & 9 & 5 & 5 & \\
\hline $\mathrm{C}_{4}(\mathrm{Pd}(\mathrm{II}))$ & 18 & 5 & Zero & 9 \\
\hline $\mathrm{L}_{\mathrm{III}}$ & 6 & 8 & Zero & 9 \\
\hline $\mathrm{C}_{11}(\mathrm{Co}(\mathrm{II}))$ & 3 & 10 & 14 & 9 \\
\hline $\mathrm{C}_{12}(\mathrm{Ni}(\mathrm{II}))$ & Zero & 12 & 11 & \\
\hline $\mathrm{C}_{13}(\mathrm{Pd}(\mathrm{II}))$ & 3 & Zero & 11 & \\
\hline
\end{tabular}

complexing behaviours and geometries using the studied metal ions.

(4) The results of the physical properties and spectral analyses of cobalt complexes prepared by template reaction demonstrated the recommendation of for synthesis of metal complexes of the studied ligands, due to less time consuming and in general more yield of products.

(5) The study of biological activity of the studied ligands and some of their metal complexes against bacteria and fungi showed selectivity nature of microorganism towards these compounds and indicated the possibility of using some of them as antibacterial and antifungal agents.

\section{References}

[1] G. Cerhiaro and A. M. D. Ferreira, "Oxindoles and copper complexes with oxindole-derivativesas potential pharmacological agents," Journal of the Brazilian Chemical Society, vol. 17, no. 8, pp. 1473-1485, 2006.

[2] S. N. Pandeya, S. Smitha, M. Jyoti, and S. K. Sridhar, "Biological activities of isatin and its derivatives," Acta Pharmaceutica, vol. 55, pp. 27-46, 2005.

[3] V. K. Sharma, S. Srivastava, and A. Srivastava, "Novel coordination complexes of the trivalent ruthenium, rhodium and iridium with hydrazones derived from isatin hydrazide and various aldehydes with spectral and biological characterization," Polish Journal of Chemistry, vol. 80, pp. 387-396, 2006.

[4] V. K. Sharma, A. Srivastava, and S. Srivastava, "Synthetic,structural and antifungal studies of coordination compounds of $\mathrm{Ru}(\mathrm{III}), \mathrm{Rh}(\mathrm{III})$ and $\mathrm{Ir}(\mathrm{III})$ with tetradentat Schiff bases," Journal of the Serbian Chemical Society, vol. 71, no. 8-9, pp. 917-928, 2006.

[5] R. M. Abdel Rahman, Z. El Gendy, and M. B. Mahmoud, "Synthesis of some new 3-substituted 1,2,4-triazino-indole derivatives and related compounds of potential antifungal activity," Indian Journal of Chemistry B, vol. 29, pp. 352-358, 1990.
[6] S. N. Pandeya, A. S. Raja, and J. P. Stables, "Synthesis of isatin semicarbazones as novel anticonvulsants-role of hydrogen bonding," Journal of Pharmacy and Pharmaceutical Sciences, vol. 5, no. 3, pp. 266-271, 2002.

[7] T. R. Bal, B. Anand, P. Yogeeswari, and D. Sriram, "Synthesis and evaluation of anti-HIV activity of isatin $\beta$ thiosemicarbazone derivatives," Bioorganic and Medicinal Chemistry Letters, vol. 15, no. 20, pp. 4451-4455, 2005.

[8] J. F. M. da Silva, S. J. Garden, and A. C. Pinto, "The chemistry of isatins: a review from 1975 to 1999," Journal of the Brazilian Chemical Society, vol. 12, no. 3, pp. 273-324, 2001.

[9] E. H. El Ashry, E. Ramadan, H. M. Abdel Hamid, and M. Hagar, "Microwave irradiation for accelerating each step for the synthesis of 1,2,4-triazino[5,6-b]indole-3-thiolsand their derivatives from isatin and 5-chloroisatin," Synlett, no. 4, pp. 723-725, 2004.

[10] G. Pelosi, C. Pelizzi, M. B. Ferrari, M.C. Rodríguez-Argüelles, C. Vieito, and J. Sanmartín, "Isatin 3-semicarbazone and 1methylisatin 3-semicarbazone," Acta Crystallographica Section C, vol. 61, no. 10, pp. 589-592, 2005.

[11] D. Sriram, T. R. Bal, and P. Yogeeswari, "Aminopyimidinimo isatin analogues: design of novel non-nucleoside HIV-1 reverse transcriptase inhibitors with broadspectrum chemotherapeutic properties," Journal of Pharmacy and Pharmaceutical Sciences, vol. 8, no. 3, pp. 565-577, 2005.

[12] K. C. Joshi, P. Chand, and A. Dandia, "Studies in spiroheterocycles-part II-reactions of fluorine containing indole-2,3-diones with 1,2-phenylendiamines \& 2,3diaminopyridine in different media," Indian Journal of Chemistry B, vol. 23, pp. 743-745, 1984.

[13] B. S. Joshi, M. A. Likhate, and N. Viswanathan, "Reaction of $\mathrm{N}$-acylisatins with diamines," Indian Journal of Chemistry B, vol. 23, pp. 114-116, 1984.

[14] P. De Mayo and J. J. Ryan, "The constitutution of isamic acid," Canadian Journal of Chemistry, vol. 45, no. 15, pp. 2177-2190, 1967.

[15] P. J. Werkman, A. Schasfoort, R. H. Wieringa, and A. J. Schouten, "Langmuir-blodgett films of a polymerisable N,N'disubstituted dithiooxamide coordination compound," Thin Solid Films, vol. 325, pp. 243-250, 1998.

[16] J. Muñoz, M. Gallego, and M. Valcárcel, "Speciation of copper by using a new fullerene derivative as a mixed-mode sorbent," 
Journal of Analytical Atomic Spectrometry, vol. 21, pp. 13961402, 2006.

[17] H. Al-Maydama, A. El-Shekeil, M. A. Khalid, and A. AlKarbouly, "Thermal degradation behaviour of some polydithiooxamide metal complexes," Ecletica Quimica, vol. 31, no. 1, pp. 45-52, 2006.

[18] S. Ando, D. Kumaki, J. Nishida, et al., "Synthesis, physicalproperties and field-effect transistors of novel thiazolothiazole-phenylene co-oligomers," Journal of Materials Chemistry, vol. 17, pp. 553-558, 2007.

[19] S. K. Agarwal, "Synthesis \& characterization of some mixed ligand complexes of $\mathrm{Pd}(\mathrm{II}), \mathrm{Rh}(\mathrm{III})$ and $\mathrm{Pt}(\mathrm{IV})$ with carboxylic hydrazones as primary and dithiooxamide as co-ligand," Asian Journal of Chemistry, vol. 19, no. 4, pp. 2581-2585, 2007.

[20] O. V. Mikhailov, "Complexing processes in M(II)dithiomalonamide-diacetyl triple systems $(\mathrm{M}=\mathrm{Ni}, \mathrm{Cu})$ in ethanol solution and in a metal(II)hexacyanoferrate(II) gelatin-immobilized matrix materials," Transition Metal Chemistry, vol. 30, pp. 18-21, 2005.

[21] D. D. Perrin and W. L. F. Armarego, Purification of Labortatory Chemicals, Pergamon Press, Oxford, UK, 2nd edition, 1980.

[22] T. L. Jacobs, S. Winstein, G. B. Linden, et al., Organic Syntheses Collective, vol. 3, John Wiley \& Sons, New York, NY, USA, 1955.

[23] C. Marti, "Novel approach to spiro-pyrrolidine-oxindoles and its applications to the synthesis of $( \pm)$-horsfiline and (-)spirotryprostatin B,"Ph.D. thesis, Swiss Federal Institute of Technology, Zürich, Switzerland, 2003.

[24] A. I. Vogel, Practical Organic Chemistry Qulitative Organic Analysis, Longman, London, UK, 3rd edition, 1972.

[25] E. G. Rochow, Inorganic Synthesis, vol. 218, McGraw-Hill, New York, NY, USA, 4 edition, 1960.

[26] G. Vatsa, O. P. Pandey, and S. K. Sengupta, "Synthesis, spectroscopic and toxicity studies of titanocene chelates of isatin-3-thiosemicarbazones," Bioinorganic Chemistry and Applications, vol. 3, no. 3-4, pp. 151-160, 2005.

[27] R. A. Kusanur, M. Ghate, and M. V. Kulkarni, "Copper(II), cobalt(II), nickel(II) and zinc(II) complexes of Schiff base derived from benzyl-2,4-dinitrophenylhydrazone with aniline," Journal of Chemical Sciences, vol. 116, no. 5, pp. 265-270, 2004.

[28] A. S. S. H. Elgazwy, H. T. Zaky, M. I. Mohamed, and N. G. Kandile, "2(3H)-furanones as synthons for polyamides of 1,3diazines and 1,3,5-triazines," Arkivoc, pp. 162-172, 2006.

[29] H. Hofmans, H. O. Desseyn, and M. A. Herman, "The infrared spectra of complexes with planar dithiooxamidesIII.the Ni(II) polymeric complexes," Spectrochimica Acta A, vol. 38, no. 11, pp. 1213-1220, 1982.

[30] H. O. Desseyn and M. A. Herman, "The characterization infra-red bands of primary and secondary thio-amides," Spectrochimica Acta A, vol. 23, pp. 2457-2463, 1967.

[31] R. M. Silverstein and F. X. Webster, Spectrometric Identification of Organic Compounds, John Wiley \& Sons, New York, NY, USA, 6th edition, 1997.

[32] J. R. Dyer, Applications of Absorption Spectroscopy of Organic Compounds, Prentice-Hall, Englewood Cliffs, NJ, USA, 1965.

[33] E. Labisbal, A. Sousa, A. Castineiras, J. A. Garcia-Vazquez, J. Romero, and D. X. West, "Spectral and structural studies of metal complexes of isatin3-hexamethyleneiminyl thiosemicarbazone prepared electrochemically," Polyhedron, vol. 19, pp. 1255-1262, 2000.
[34] N. M. A. Al-Abidy, "Synthesis, characterization and study of the biological activity of new Mannich- Schiff bases and some metal complexes derived from isatin, 3-amino-1,2,4-triazol and dithiooxamide," Ph.D. thesis, University of Baghdad, Baghdad, Iraq, 2006.

[35] R. V. Singh, N. Fahmi, and M. K. Biyala, "Coordination behavior and biopotency of $\mathrm{N}$ and $\mathrm{S} / \mathrm{O}$ donor ligands with their palladium(II) and platinum(II) complexes," Journal of the Iranian Chemical Society, vol. 2, no. 1, pp. 40-46, 2005.

[36] K. Nakamoto, Infrared and Ramman Spectra of Inorganic and Coordination Compounds, John Wiley \& Sons, New York, NY, USA, 5th edition, 1997.

[37] A. B. P. Lever, Inorganic Electronic Spectroscopy, Elsevier, Amsterdam, The Netherlands, 1968.

[38] N. M. A. Al-Abidy, "Synthesis and study of some transition metal complexes with $\mathrm{N}$ and S-containing Schiff bases derived from 4-phenyl-5-(P-amino phenyl)-3-mercapto1,2,4-triazol.," M.S. thesis, Baghdad University, Baghdad, Iraq, 1997.

[39] J. R. Allan, A. D. Paton, K. Turvey, D. L. Gerrard, and S. Hoey, "Thermal, structural and electrical studies of the chloro complexes of cobalt, nickel, copper and zinc with 2methylquinoxaline," Thermochimica Acta, vol. 145, pp. 291300, 1989.

[40] F. A. Cotton and G. Wilkinson, Advanced Inorganic Chemistry, John Wiley \& Sons, Singapore, 4th edition, 1980.

[41] B. N. Figgis, Introduction to Ligand Fields, Inter-Science, John Wiley \& Sons, New York, NY, USA, 1966.

[42] K. Burger, Coordination Chemistry, Experimental Methods, Butter Worth, London, UK, 1967.

[43] D. Sutton, Electronic Spectra of Transition Metal Complexes, McGraw-Hill, New York, NY, USA, 1st edition, 1968.

[44] M. J. Al-Jeboori, A. J. Abdul-Ghani, and A. J. Al-Karawi, "Synthesis and structural studies of new Mannich base ligands and their metal complexes," Transition Metal Chemistry, vol. 33, no. 7, pp. 925-930, 2008.

[45] W. J. Geary, "The use of conductivity measurements in organic solvents for the characterization of coordination compounds," Coordination Chemistry Reviews, vol. 7, pp. 81-122, 1971.

[46] C. Duval, Inorganic Thermogravimetric Analysis, Elsevier, London, UK, 2nd edition, 1963.

[47] T. L. Zhang, J. C. Song, J. Guo, G. X. Ma, and K. B. Yu, "Syntheses, crystal structures and thermal stability of Co(II) and $\mathrm{Zn}$ (II) complexes with ethyl carbazate," Zeitschrift für Naturforschung B, vol. 60, pp. 505-510, 2005.

[48] P. A. Antunes, S. T. Breviglieri, G. O. Chierice, and E. T. G. Cavalheiro, "Solution and solid state thermal stability of morpholine dithiocarbamates," Journal of the Brazilian Chemical Society, vol. 12, no. 4, pp. 473-480, 2001.

[49] A. J. Abdul-Ghani and R. A. Majeed, "Preparation and characterization of new metal complexes of Schiff bases contaning a thiazole ring," Iraqi Journal of Science, vol. 46, no. 1, pp. 59-74, 2005. 


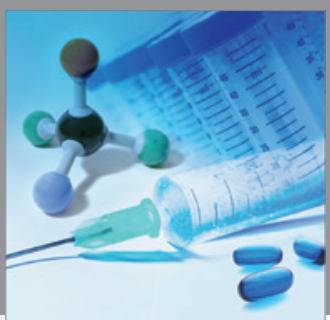

International Journal of

Medicinal Chemistry

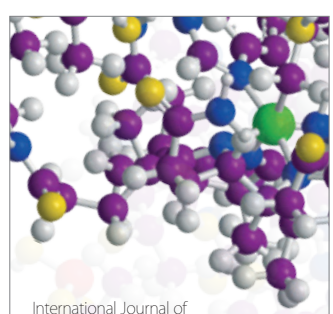

Carbohydrate Chemistry

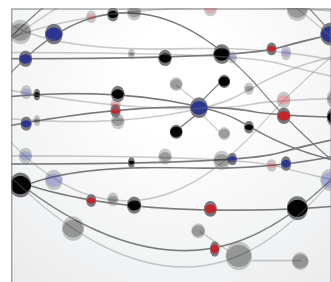

The Scientific World Journal
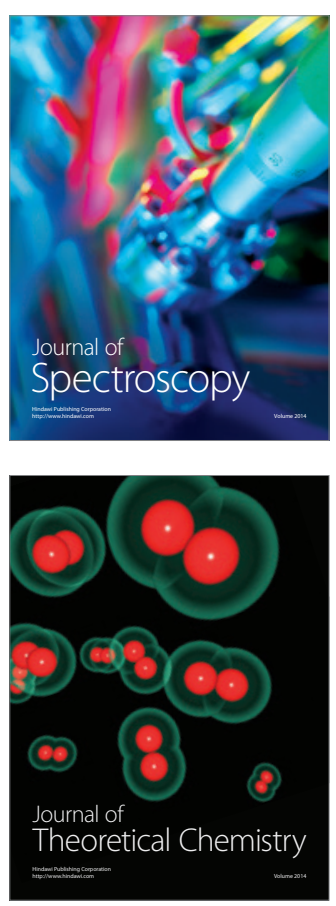
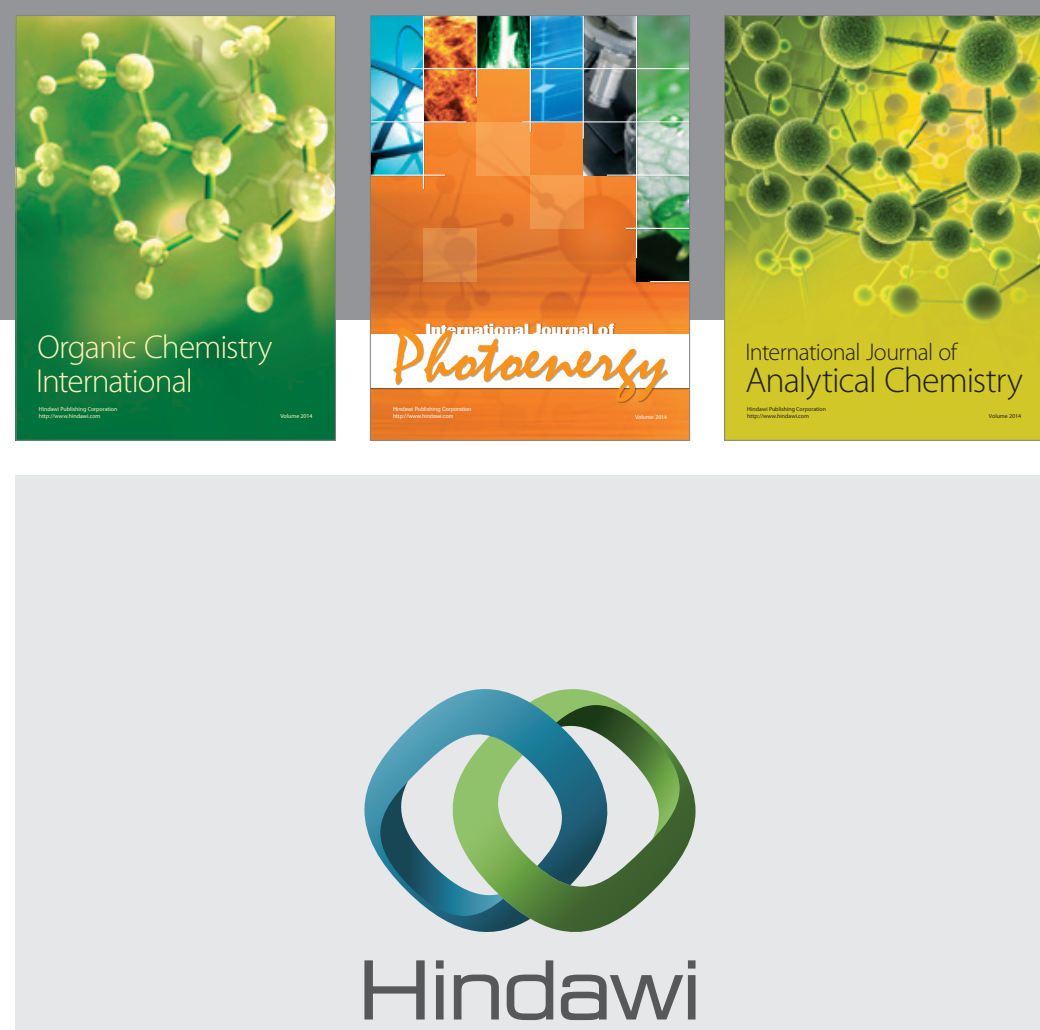

Submit your manuscripts at

http://www.hindawi.com
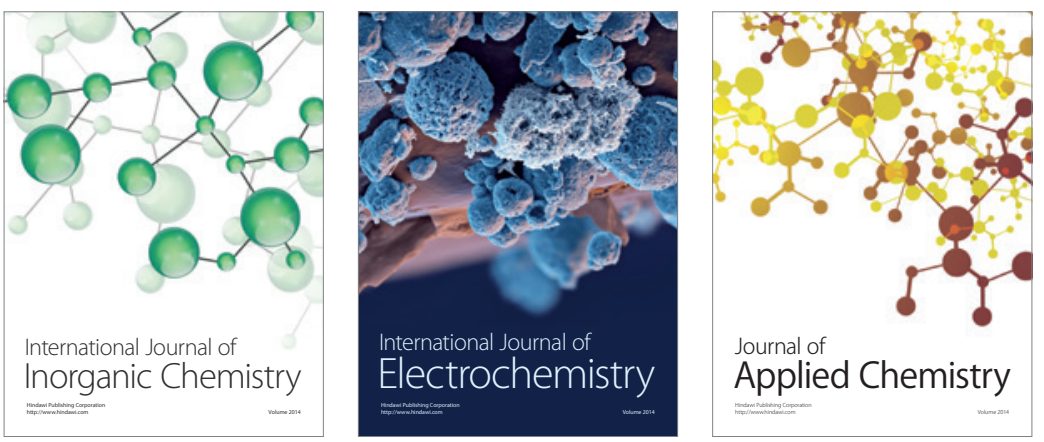

Journal of

Applied Chemistry
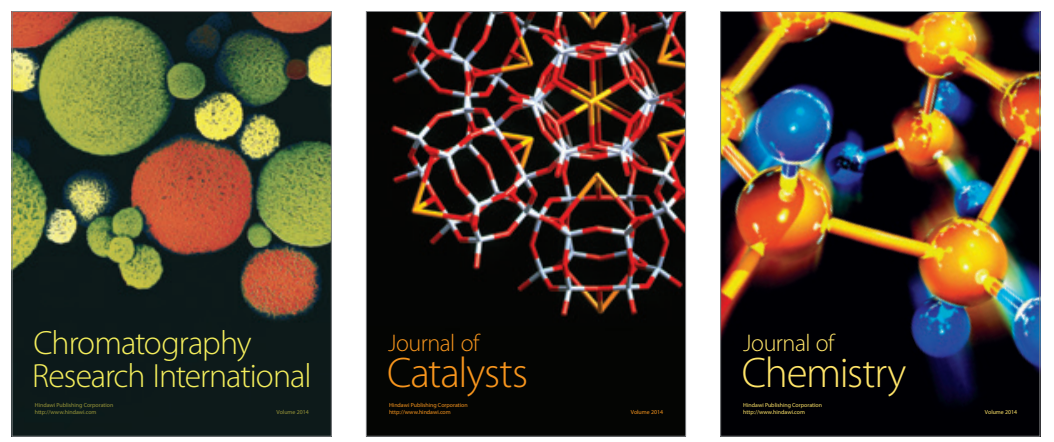
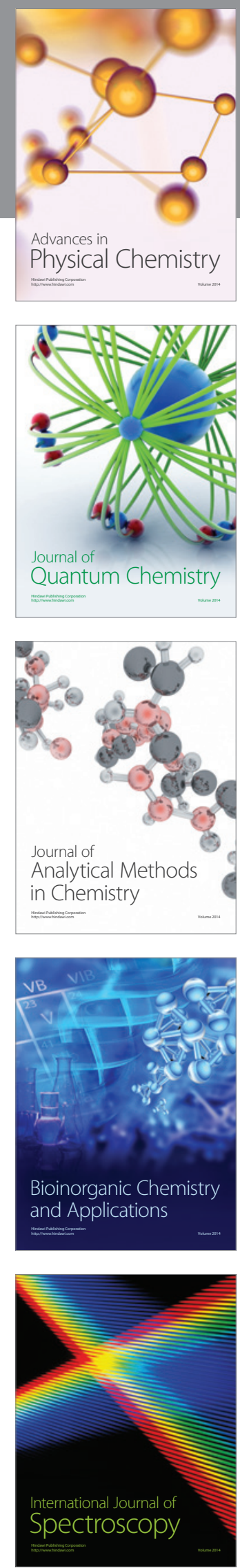